4-2021

\title{
Patient Satisfaction With Noise
}

Robert W. Kentner II

University of St. Augustine for Health Sciences, r.kentner@usa.edu

DOI: https://doi.org/10.46409/sr.YAPX6652

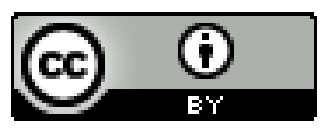

This work is licensed under a Creative Commons Attribution 4.0 License.

Follow this and additional works at: https://soar.usa.edu/scholprojects

Part of the Nursing Commons, and the Quality Improvement Commons

\section{Recommended Citation}

Kentner, R. W. (2021). Patient Satisfaction With Noise. [Doctoral project, University of St Augustine for Health Sciences]. SOAR @ USA: Student Scholarly Projects Collection. https://doi.org/10.46409/ sr.YAPX6652

This Scholarly Project is brought to you for free and open access by the Student Research at SOAR @ USA. It has been accepted for inclusion in Student Scholarly Projects by an authorized administrator of SOAR @ USA. For more information, please contact soar@usa.edu, erobinson@usa.edu. 
Patient Satisfaction With Noise

Robert William Kentner II, MSN, RN, CPHQ, CEN, TCRN

School of Nursing, University of St. Augustine for Health Sciences

This Manuscript Partially Fulfills the Requirements for the

Doctor of Nursing Practice Program and is Approved by:

Dr. Sheri Jacobson, PhD, RN

Dr. Adrienne Olson, DNP, RN, FACHE

Approved March 21, 2021 


\begin{abstract}
Practice Problem: Noise on hospital units can interfere with patient rest, timely recovery, and statisfacton with care. Improvements in the reduction of hospital noise levels lead to improved patient satisfaction and improved rest. Patients were surveyed on their satisfaction with noise during the day and at night.
\end{abstract}

PICOT: In Acute Care Patients (P), does the implementation of a noise reduction program (I) compared to no noise reduction program $(\mathrm{C})$, affect patient satisfaction with noise $(\mathrm{O})$ over a sixweek period $(\mathrm{T})$ ?

Evidence: Studies show that many hospitals have noise levels that exceed the World Health Organization's recommended standards for noise levels. Evidence showed that implementing a noise reduction program that included quiet times and sleep menus produced an increase in patient satisfaction with noise.

Intervention: Implementation of a noise reduction program and establishing a two-hour quiet time during the day. The program also established a sleep menu to identify and support patient bedtime rituals.

Outcome: The implementation of a noise reduction program showed a statistical decrease in measurable noise levels. The project produced a clinically significant increase in patient satisfaction during the day and a clinically significant improvement in patient satisfaction with sleep quality and quantity.

Conclusion: The goal of the noise reduction project was to improve the patients' overall satisfaction with hospital noise during the day and overnight. This project showed that a noise reduction program could decrease noise levels and improve patient satisfaction with noise. 


\section{Patient Satisfaction With Noise}

Improvements in the reduction of hospital noise levels lead to improved patient satisfaction as well as improved rest. Patients are surveyed on their satisfaction with noise at night. These survey scores are public information. Low satisfaction scores can lead new and existing patients to seek other healthcare facilities for their healthcare needs.

This paper describes a Doctor of Nursing Practice (DNP) project for a noise reduction program to improve satisfaction with noise for acute care patients. The project started with a discussion of the significance of the problem and the PICOT question. The change theory and framework were discussed, a review of the literature was conducted, as well as an overview of the theme(s) identified in the literature. From the theme(s), a practice recommendation was developed. The project setting and plan were described to include the method, evaluation, and sustainability of the project.

\section{Significance of the Practice Problem}

Florence Nightingale (1860) stated that erratic noise is harmful to the patient. Her studies showed that rest was essential to patient recovery, and noise interrupted the patient's rest. She advocated for hospital wards to be as quiet as possible (Nightingale, 1860). The Center for Medicare and Medicaid Services (CMS) has developed a method of grading the performance of each healthcare facility. This method is called the Hospital Consumer Assessment of Healthcare Providers and Systems (HCAHPS). Each inpatient is surveyed, and one of the questions addresses satisfaction with noise at night. The results of these surveys are published as part of the HCAHPS scores. The scores are also used in the calculation of hospital reimbursement rates from CMS. This means lower satisfaction scores may lead to lower reimbursement rates (CMS, n.d.-a). 
The hospital's scores for patient satisfaction of noise levels at night are lower than other items scored in the survey. While the hospital's noise satisfaction levels are on par with the national averages, these scores are below the state of Nebraska's average. The facility has a noise satisfaction rating of $61 \%$, while state satisfaction with noise levels is $70 \%$, and the national average is $62 \%$ (CMS, n.d.-b).

The World Health Organization (WHO) has published a report on the negative effects of noise in European countries. This report showed that noise levels above 45 decibels $(\mathrm{dB})$ had caused sleep interruption and decreased rest (WHO, 2009). To bring this into perspective, libraries and quiet offices have noise levels of $40 \mathrm{~dB}$ (Center for Hearing and Communication, n.d.). In comparison, a normal conversation produces noise levels at $60 \mathrm{~dB}$ (Center for Disease Control and Prevention, 2019).

Using Hospital Compare and HCAHPS scores, patients and families can research each hospital (Centers for Medicare and Medicaid Services, n.d.-b). This research provides a mechanism for patients and families to shop for a preferred hospital. With these choices, patient satisfaction scores become important for continued return patients as well as developing new patient relationships. A decrease in patient population will cause a reduction in hospital revenue. The reduction in revenue, combined with a decrease in CMS reimbursement, will have a negative impact on the facility's financial health.

\section{PICOT Question}

The following population, intervention, change, outcome, and time (PICOT) question was used. In Acute Care Patients (P), does the implementation of a noise reduction program (I) compared to no noise reduction program (C), affect patient satisfaction with noise $(\mathrm{O})$ over a 6week period (T)? This problem addressed patients across all age and gender boundaries. Any 
patient admitted for a minimum of one overnight stay in the medical-surgical unit (MSU) was part of the target population for this project.

The intervention was a noise reduction program with reduction of noise at night and a quiet time blocked out during the day. These interventions included decreasing the volume of alarms and monitors to a lower level that could still be heard by staff to provide safe and effective monitoring of the patient (Kaur et al., 2016). A 2-hour quiet time was implemented from 1 p.m. to 3 p.m. daily. During this quiet-time, lighting levels were reduced in patients' rooms, and room doors were closed. Staff limited patient interactions to only those specific interactions needed to provide safe and effective patient care (Steaphen et al., 2017). Attempts were made to schedule all medications, lab sampling, and testing outside of the quiet time. Nurses, when possible, scheduled routine assessments and rounds outside of quiet time. Patient families were educated about quiet-time and the need for patient rest. Families were requested to limit patient visits and interactions during this time (Rice, 2010). When patient interactions were unavoidable, they were limited to only what was necessary for safe and effective patient care.

The comparison was normal day time activities with no special attempts to reduce sound levels. Normal daily activities meant that lights were maintained at normal daytime levels, and patient doors may have remained open throughout the day. Patient interactions with staff occurred as scheduled or when new orders were received. All testings were performed when the order was received and could be scheduled with the appropriate service. Nursing assessments were performed as scheduled and when convenient for the nurse. Provider rounds occurred when the provider found it convenient to perform this duty. Alarm and monitor volumes were maintained at the level that was preset with no decrease in volume (Adatia et al., 2014). 
A survey tool was used to measure patient satisfaction with noise (Applebaum et al., 2016). This project was conducted over six weeks. Patient surveys were conducted during discharge. This allowed enough time to collect noise and survey data that was significant to detect overall and sustained change. The sound data and surveys were reviewed weekly at the performance improvement meeting.

\section{Quality Improvement Framework and Change Theory}

This project used the knowledge-to-action (KTA) process framework. Quality assurance and the understanding of evidence-based practice has been around for many years. There was still a gap between the knowledge and the application in practice. The KTA process was developed to help minimize this gap and create a tool to transfer the knowledge into actions (Graham et al., 2006).

The KTA process is highly adaptable for individuals, teams, and organizations. This process is an eight-phase process designed to work well in healthcare organizations. The first phase is identifying the problem. Once the problem is identified, the next phase is to identify and review the knowledge relevant to the problem. After the knowledge has been identified and reviewed, the third phase is to adapt this knowledge to the local context. The fourth phase is to look for possible barriers to the use of the identified knowledge. The next phase is to develop and implement interventions to use this knowledge. The last three phases are to monitor the use of the knowledge, evaluate the outcome, and then sustain the use of the knowledge (Graham et al., 2006). See (Figure 1) for the Knowledge to action process diagram.

Kurt Lewin's theory of change was used as the change theory for this project. The theory provided a simple change structure with which many individuals are familiar. There were three phases in this change theory. The first phase was to unfreeze the current situation. This could be 
accomplished by increasing the driving force of the change or decreasing the resistance to the change. This was accomplished by the education of the noise problem and its effect on patient satisfaction as well as causes of excessive noise. The second phase was moving or changing in which the institution moved to a new equilibrium. This phase was the implementation of the noise reduction program and monitoring the change. Refreezing was the final phase and was accomplished with maintaining the change and applying it to other inpatient settings within the organization. This was the point where the change was sustained within the institution (Lewin, 1957, as cited in White, 2016).

\section{Evidence Search Strategy}

A search of databases was performed that included: Cumulative Index to Nursing and Allied Health Literature (CINAHL), PubMed, and ProQuest. Searches were conducted to find literature specific to the following PICOT question. In Acute Care Patients (P), does the implementation of a noise reduction program (I) compared to no noise reduction program (C), affect patient satisfaction with noise $(\mathrm{O})$ over a six-week period $(\mathrm{T})$ ? The headings and keywords for the initial search used the terms: noise, patient, satisfaction, and hospital. These terms were placed in a Boolean argument of "noise AND patient AND satisfaction AND hospital." To ensure current literature was referenced, the search was limited to articles published in 2015 through 2020. The searches were limited to peer reviewed articles in academic journals with a subject of noise and written in English. A second set of searches was performed using the terms: sleep, disruption, noise, and hospital. These terms were then placed in a Boolean argument of “sleep AND disruption AND noise AND hospital." As with the first search, this search was limited to articles published in 2015 through 2020, as well as articles in academic journals that were peer-reviewed with a subject of noise and written in English. A review of the titles and 
abstracts was performed using the following inclusion criteria: noise reduction, acute care setting, and review of patient satisfaction surveys. All studies that met the inclusion criteria were retrieved and evaluated to determine final eligibility. This final evaluation was performed to ensure the articles used were research articles.

\section{Evidence Search Results and Evaluation}

A search of databases was performed that included: Cumulative Index to Nursing and Allied Health Literature (CINAHL), PubMed, and ProQuest. The headings and keywords for the initial search used the terms: noise, patient, satisfaction, and hospital. These terms were placed in a Boolean argument of "noise AND patient AND satisfaction AND hospital." To ensure current literature is referenced, the search was limited to articles published in 2015 through 2020 . The searches were limited to peer reviewed articles in academic journals with a subject of noise and written in English. A second set of searches was performed using the terms: sleep, disruption, noise, and hospital. These terms were then placed in a Boolean argument of "sleep AND disruption AND noise AND hospital." As with the first search, this search was limited to articles published in 2015 through 2020, as well as articles in academic journals that were peer-reviewed with a subject of noise and written in English.

The initial database search produced 70 articles. The second search produced 78 articles. The combined database searches produced 124 individual articles. A review of the titles and abstracts was performed using the following inclusion criteria: noise reduction, acute care setting, and review of patient satisfaction surveys. The inclusion criteria review produced 45 articles. All studies that met the inclusion criteria were retrieved and evaluated to determine final eligibility. This final evaluation was performed to ensure the articles used were research articles. 
This produced a total of 16 research articles for further evaluation. See Figure 2 for the Prisma flow diagram

The level and quality of the evidence was evaluated using the Johns Hopkins Nursing Evidence Based Practice Evidence Level and Quality Guide (Dang \& Dearholt, 2018). Table 1 describes the criteria.

\section{Table 1}

Johns Hopkins Nursing Evidence Based Practice Evidence Level and Quality Guide

\begin{tabular}{|l|l|}
\hline Evidence Levels & Quality Guides \\
\hline $\begin{array}{l}\text { Level I } \\
\text { Experimental study, randomized } \\
\text { controlled trial (RCT) } \\
\text { Systematic review of RCTs }\end{array}$ & $\begin{array}{l}\text { A High quality: Consistent results; sufficient } \\
\text { sample size design; adequate control; } \\
\text { definitive conclusions; consistent } \\
\text { recommendations that includes thorough } \\
\text { reference to scientific evidence } \\
\text { Bevel II } \\
\begin{array}{l}\text { Quasi-experimental study } \\
\text { Systematic review of a combination of RCTs } \\
\text { and quasiexperimental, or quasi- } \\
\text { experimental studies only }\end{array}\end{array}$ \\
$\begin{array}{l}\text { Level III } \\
\text { results; sufficient sample size; some control, } \\
\text { fairly definitive conclusions; reasonably } \\
\text { consistent recommendations } \\
\text { Systematic review of a combination of RCTs, } \\
\text { quasi-experimental and non-experimental } \\
\text { studies, or non-experimental studies only }\end{array}$ & $\begin{array}{l}\text { with inconsistent results; insufficient sample } \\
\text { size; conclusions cannot be drawn }\end{array}$ \\
\hline
\end{tabular}

Note. Adapted from Johns Hopkins Nursing Evidence Based Practice Evidence Level and

Quality Guide (3 ${ }^{\text {rd }}$ ed.), by Dang, D. and Dearholt, S. L., 2018, Sigma Theta Tau International (https://www.sigmamarketplace.org/johns-hopkins-nursing-evidence-based-practice-model-andguidelines-third-edition). Copyright 2018 by Sigma Theta Tau International.

The review of literature produced three studies at Level I experimental studies, six studies at Level II quasi-experimental studies, and seven studies at Level III non-experimental (see Appendix B). Only two studies showed to be of low quality. There were 13 studies of good 
quality or higher. The good quality or higher studies consisted of three Level I, five Level II, and five Level III.

\section{Themes from the Evidence}

The issue of excessive noise in the hospital was documented in several studies. These studies noted that nighttime sound levels could regularly exceed $50 \mathrm{~dB}$. Daytime noise levels could average as high as $75 \mathrm{~dB}$ with spikes as high as $90 \mathrm{~dB}$ (Christofel et al., 2016; Delaney et al., 2017, 2018; Ryan et al., 2016; Zamani et al., 2018). Six of the studies, that were rated of good quality or better using Johns Hopkins Nursing Evidence-Based Practice Evidence Level and Quality Guide, measuring noise levels. Of these six, four were in an intensive care unit (ICU), and two were in MSUs. All six studies reported excessive noise levels (Christofel et al., 2016; Delaney et al., 2017, 2018; MacKay et al., 2019; Ryan et al., 2016; Zamani et al., 2018). These sound levels exceeded the WHO's recommendations for healthcare settings to maintain nighttime sound levels below $30 \mathrm{~dB}$ and daytime sound levels below $35 \mathrm{~dB}$ (Berglund et al., 1999).

When a noise reduction program was implemented, patients perceived a reduction in noise levels. The program also correlated to an improvement in the patients' overall satisfaction with noise. Three of the studies reviewed showed that patient satisfaction improved when there was a perception by the patient of noise reduction. The three studies on patient perception of noise were rated at good quality Johns Hopkins Nursing Evidence-Based Practice Evidence Level and Quality Guide, two were in an ICU, and one was in an MSU (Applebaum et al., 2016; Mutair et al., 2019; Younis et al., 2020). One of the studies showed that during the implementation of a noise reduction program that included daytime quiet time, the perception of 
noise reduction occurred despite no actual reduction in measurable noise levels (Applebaum et al., 2016).

The causes of sleep disturbances were from four sources. These sources were staff interventions, noise, light, and room temperature. Staff interventions were the highest cause of sleep disturbances followed by noise (Delaney et al., 2018; Gulam et al., 2020; Mutair et al., 2019; Stickland et al., 2016; Stremler et al., 2015; Younis et al., 2020). Delaney et al. (2018) noted in their study that the expectation of both staff and patients was for the patient to experience reduced levels of sleep and rest while in the hospital.

Noise reduction strategies included staff education, implementation of quiet-time, staff behavior modification, and identification and mitigation of equipment noise sources (Applebaum et al., 2016; Delaney et al., 2018; Kaur et al., 2016; Stickland et al., 2016). Primary sources of noise were staff conversations, monitors and alarms, noise from other patients, and families (Applebaum et al., 2016; Christofel et al., 2016; Delaney et al., 2017; Ryan et al., 2016; Stremler et al., 2015).

The implementation of a daytime quiet time improved patients' perception of noise as well as their quality of rest. The quiet time was set as 1 to 2 hours in the afternoon with reduced noise. This time was also used to limit staff interventions to promote rest (Applebaum et al., 2016; Clark \& Mills, 2017; Tabas et al., 2019; Waller-Wise \& Mad, 2019).

Processes to improve sleep at night included noise reduction and the wearing of eye masks and earplugs (Applebaum et al., 2016; Clark \& Mills, 2017; Delaney et al., 2018; Tabas et al., 2019). In addition to eye masks and earplugs, Clark and Mills (2017) developed a sleep menu for patients to use that included options that the patient may have in their regular bedtime routine. 


\section{Practice Recommendations}

Excessive noise was a leading theme in the research (Christofel et al., 2016; Delaney et al., 2017, 2018; Ryan et al., 2016; Zamani et al., 2018). From the beginning of nursing as a formalized training, Florence Nightingale stated that excessive noise was detrimental to the health and recovery of the patient (Nightingale, 1860). Poor rest in hospitals can lead to increased problems with hypertension, hyperglycemia, delirium, and slower recovery. The studies showed that sleep had a positive effect on patient recovery and the speed of recovery (Duss et al., 2017; Stewart \& Arora, 2018; Zhang et al., 2020).

A formal noise reduction protocol was implemented (Applebaum et al., 2016; Delaney et al., 2018; Kaur et al., 2016; Stickland et al., 2016). Part of the program was the establishment of a 2-hour daytime quiet period running from 1 p.m. to 3 p.m. This quiet period included the dimming of lights and closing of patient doors. Staff interactions with patients were minimized to those items that were necessary for patient health and safety. All non-critical activities were scheduled outside of this quiet-time (Applebaum et al., 2016; Clark \& Mills, 2017; Tabas et al., 2019; Waller-Wise \& Mad, 2019).

Education was needed to assist the staff in understanding what excess noise is and the causes of excess noise. The causes of excessive noise could include staff conversations, monitors and alarms, noise from other patients, and families (Applebaum et al., 2016; Christofel et al., 2016; Delaney et al., 2017; Ryan et al., 2016; Stremler et al., 2015). The education also needed to include why noise control was important and how the staff could actively participate in the elimination of noise to provide a restful environment for the patients (Applebaum et al., 2016; Delaney et al., 2018; Kaur et al., 2016; Stickland et al., 2016). 
Patient preferences for a restful night were noted and provided to the best of the staff's ability. These preferences could include such items as door closure, light brightness, warm blankets, bedtime snacks, eye masks, and earplugs (Applebaum et al., 2016; Clark \& Mills, 2017; Delaney et al., 2018; Tabas et al., 2019). To facilitate the communication of the patient's bedtime ritual requests, a sleep menu that lists the patient's individual preferences was used as a communication tool (Clark \& Mills, 2017).

\section{Project Setting}

This project was implemented in the MSU of a physician owned acute care hospital in central Nebraska. The MSU was a 23-bed facility with all beds in private rooms. The unit was laid out in a "T" shape with the nurses' station at the intersection of the "T." The MSU supported both medical and surgical patients that needed hospitalization but did not need the advanced care of a post-critical unit (PCU) or ICU.

The organization had a mission to improve the health of the population served, with a commitment to excellence. The organization's vision was to provide advanced medical care, in a network, that was physician guided. This care needed to be inspired by the community and be compassionate, personal, and innovative.

A vertical organizational structure was used. The chief executive officer had senior executives that reported to him. Each executive was responsible for one or more departments with department directors reporting to that executive. This allowed for faster decision making as well as increased accountability at all levels. The disadvantage of this type of structure was the possible isolation between branches. This could create reduced inter-department communications and collaboration (Society for Human Resource Management, 2015). 
A culture of innovation was promoted at all levels of the organization. Members were encouraged to bring innovative ideas to management for consideration and possible implementation. All departments in the organization were actively looking to change and improve the care provided. Change could be small or large. The important part of the change must be focused on patient safety and satisfaction.

The CMS collects quality data on all hospitals receiving Medicare or Medicaid payments for reimbursement. This information is collected and recorded in the HCAHPS (CMS, n.d.-a). This data is public information and reported on Hospital Compare. Currently, the organization had a rating of $61 \%$ for the quiet at night question. The state average for the same question was $70 \%$, and the local competing hospital had a score of $60 \%$ (CMS, n.d.-b). This, as well as observations by leadership at all levels, identified noise in the hospital as an issue.

All personnel and groups that provided services or interacted with the patients in the MSU were stakeholders in the project. This included the leadership for these groups. The stakeholders were medical staff, nursing staff, radiology staff, surgery staff, respiratory staff, laboratory staff, dietary staff, rehabilitation services staff, pharmacy staff, housekeeping staff, and facilities staff. Along with these staff members, the patients and their families were also stakeholders in this project.

Support for this project was shown from the start. The chief nursing officer determined that noise was an issue that needed to be addressed and requested that a project be developed to reduce noise and improve patient satisfaction with noise. Once the noise reduction program was implemented within the MSU, management continued to reinforce the need for noise reduction and continued use of the tools implemented for the project. Upon completion and evaluation of 
the noise reduction program within the MSU, this same project was implemented in other inpatient units throughout the facility.

The organization promoted interprofessional collaboration and communication. This collaboration was accomplished through regular meetings with many disciplines represented. One example of this was the Clinical Leadership Team (CLT). The CLT met weekly to discuss any current issues and trends. All individuals had equal input and all input was valued. As action items were identified, they were assigned to the appropriate area of the organization with due dates for completion of report. The results of these meetings ensured that all parts of the organization were communicating to prevent isolation.

The strengths, weaknesses, opportunities, threats (SWOT) analysis (see Appendix C) showed that the organization was forward-thinking and readily embraces needed change. There was a limitation on the needed space, which was being addressed with an expansion project. The major threat to the organization was competing facilities, both locally and regionally.

\section{Project Overview}

The mission of this project was to provide a quiet and restful environment for the patients and their families to promote healing. The vision of the project was to contribute to the compassionate care of the patient. These aligned with the organization's mission of promoting community health and the vision of providing personal, compassionate, and innovative care.

There were two short-term objectives for the noise reduction project. The first objective was to reduce hospital noise in the MSU. The other objective was to improve patient and family satisfaction with noise. The long-term objective was to expand the project throughout the facility with the ultimate goal of improving the HCAHPS score for noise at night. 
The risks and unintended consequences included the possibility that noise levels did not decrease. There was the possibility of missed medication during quiet times. Decreased alarm volumes could lead to longer response times for alarms. Ancillary departments may have had a risk of conflict in performing their needed duties such as room and floor cleaning.

\section{Project Plan (Method)}

This project used the KTA process, which was developed as a tool to transfer knowledge into action. The KTA process was highly adaptable for individuals, teams, and organizations. The first phase was identifying the problem. Once the problem was identified, the next phase was to identify and review the knowledge relevant to the problem. After the knowledge had been identified and reviewed, the third phase was to adapt this knowledge to the local context. The fourth phase was to look for possible barriers to the use of the identified knowledge. The next phase was to develop and implement interventions to use this knowledge. The last three phases were to monitor the use of the knowledge, evaluate the outcome, and then sustain the use of the knowledge. The KTA model was a continuous process that loops back to identifying the problem and then researching, developing, and implementing a solution (Graham et al., 2006).

\section{Identify a Problem That Needs Addressing}

According to Hospital Compare, $61 \%$ of patients stated that the area outside their room was quiet at night. This compared to an average of $70 \%$ for the state (CMS, n.d.-b). The hospital decided to address the overall noise in the facility.

\section{Identify, Review, and Select the Knowledge or Research Relevant to the Problem}

A literature search was performed. The relevant research was reviewed and synthesized. The results of the literature review are shown in the evidence search strategy, evidence search results and evaluation, and themes from the evidence sections of this document. This research 
showed that the implementation of a noise reduction program, along with the use of sleep menus, increases the patient's satisfaction with noise in the hospital (Applebaum et al., 2016; Mutair et al., 2019; Younis et al., 2020).

\section{Adapt the Identified Knowledge or Research to the Local Context}

The research identified in the literature review was conducted in medical-surgical, postcritical, intensive care, and maternal units. Results from research in the non-MSUs were similar to the MSU. The research showed the use of noise reduction education, monitoring, quiet-times, and sleep menus were effective in reducing noise and improving patient satisfaction with noise (Applebaum et al., 2016; Clark \& Mills, 2017; Delaney et al., 2018; Kaur et al., 2016; Stickland et al., 2016; Tabas et al., 2019). All results could easily be adapted to the local context.

\section{Assess Barriers to Using the Knowledge}

Staff might have been resistant to change. Medical and ancillary services might have resisted rescheduling of non-emergent tasks to hours outside of "Quiet-Time." Visitors might not have cooperated with noise reduction initiatives. Staff might not have been motivated or feel that the change was important.

\section{Select, Tailor, and Implement Interventions to Promote the Use of Knowledge}

A sound level meter (REED Instruments R8070SD Sound Level Meter) was placed at the nurses' station. This meter continuously monitored and recorded sound levels. The meter had internal storage that was downloaded weekly for review. A visual feedback device (TestHelper SW-525A Sound Level Meter) was placed at the nurses' station to alert staff when noise levels exceeded recommended limits. Two-hour daytime quiet-time was implemented from 1 p.m. to 3 p.m. Signs were posted throughout the inpatient wing explaining quiet-time. Patients and families were educated on quiet time. During quiet-time, patient-staff interactions were 
minimized. Nurses attempted to schedule all medications and interventions outside of quiet-time hours. Providers were requested to perform all non-emergent patient interactions outside of quiet time. Non-emergent tests and procedures were not be performed during this period. All ancillary staff (i.e., housekeeping, food services, etc.) minimized working in or around inpatient rooms during the quiet-time hour.

The education of all staff and supervisors was performed by the project manager. The staff that was trained included but was not limited to medical staff, nursing staff, radiology staff, surgery staff, respiratory staff, laboratory staff, dietary staff, rehabilitation services staff, pharmacy staff, housekeeping staff, and facilities staff. This education included noise sources, ways to mitigate the noise, and the impact of noise on patient rest, healing, and satisfaction (see Appendix D). All staff monitored perceived noise levels and reported any sources of perceived excessive noise. Staff also worked to minimize excessive noise by lower alarm volumes, closing patient doors, and minimizing loud conversations.

Six-weeks prior to the implementation of the quiet-time hour, patients started receiving the Patient Survey on Noise During Hospital Stay at their discharge (see Appendix E). The survey used a paper form. This survey was developed for Applebaum et al. (2016) and was used with the permission of the developer (see Appendix F)(D. Applebaum, personal communications, July 1, 2020). The surveys continued to be used throughout the entire project.

Prior to implementation, the sound meter was installed. The training of supervisors and staff was completed, and the pre-implementation surveys were completed. The project intervention ran for six weeks before the final evaluation was performed, and the data compiled for reporting. The timeline is shown in (Appendix G). The projected budget for the project is shown in (Appendix H). 
During the project, a sleep menu was implemented. The options on the sleep menu were developed with input for the MSU staff and leadership. This sleep menu was part of the patient communication board in each room. This sleep menu was used to communicate patient preferences for nighttime rituals that promoted rest (see Appendix I). The unit aides discussed with the patient and entered sleep menu preferences onto the patient communications board. In the evening, the unit aides ensured that patient preferences were implemented.

\section{Monitor Knowledge Use}

Sound meter readings were used to measure quantitative noise levels. The readings were used to trend noise levels during the project. All patients received the Patient Survey on Noise During Hospital Stay during their discharge education. All surveys were reviewed for trends and patient feedback. The hospital's leadership rounded daily to determine if quiet time was being implemented and recorded the results for analysis and final reporting.

The project manager compiled and analyzed all data from the surveys and sound monitoring equipment. This data was used to provide ongoing feedback to staff and leadership. All surveys were reviewed for trends and patient feedback. The results of this analysis were provided to the staff and leadership. The results were presented at the leadership and staff meetings. The project manager facilitated discussion of possible improvements or identifying and resolving any concerns of the staff and leadership.

\section{Results}

This section will review the results of the project. An analysis of the project was performed to determine if the there was a statistical or clinical significance to the project. 


\section{Recruitment and Selection of Participants}

All patients discharged from the MSU were asked to complete the Patient Survey on Noise During Hospital Stay. The patient had the option to refuse participation. Patients with known hearing impairments were excluded from the survey data.

\section{Data Collection}

Sound meter readings were used to measure the quantitative change in noise levels. Noise level satisfaction was determined by surveys given to the patients during their discharge education. Survey data was collected 6 weeks before the start of the project to provide baseline patient satisfaction levels. Baseline sound level data was collected for 6 weeks before the implementation of the project. The baseline data and discharge surveys were used to determine the outcome of the project.

Noise satisfaction scores were obtained with discharge surveys and used to measure patient satisfaction with noise levels. The tool used was the Patient Survey on Noise During Hospital Stay, as seen in Appendix E. This tool consisted of four items on a five-point Likert scale. The scale was: strongly agree, agree, neither, disagree, and strongly disagree. These four questions measured the patient's satisfaction with noise in the hospital. An additional five items using the same Likert scale were used to assess the quiet-time implementation's efficacy. There were five questions used to help identify sources and times of noises that disturb the patients. Additional questions included sex, age, and length of stay. No personal identifying information was collected.

Noise levels were continuously monitored using a permanently placed sound monitor using a REED Instruments R8070SD Sound Level Meter. This ensured that noise monitoring was valid and reliable. 


\section{Data Collection, Analysis, and Storage}

Discharge nurses provided all patients being discharged with a copy of the Patient Survey on Noise During Hospital Stay during their discharge education. The patients were requested to complete the survey before leaving the hospital. The completed survey forms were stored in the unit manager's office and then collected by the project manager. The survey forms were then scanned electronically and stored in encrypted cloud storage. The original forms were then shredded.

Sound data were collected using a REED Instruments R8070SD Sound Level Meter. This meter had internal storage for sound data collected. The project manager downloaded the data from the sound meter weekly.

The project manager collected and compiled all data and performed the analysis. The data were stored in cloud storage. The files were encrypted using Advanced Encryption Standard (AES) 256-bit encryption (Nechvatal et al., 2001). This ensured redundancy as well as the security of the data.

\section{Data Source Integrity}

Patient satisfaction data were collected using the Patient Survey on Noise During Hospital Stay, as seen in Appendix E. This survey was developed for Applebaum et al. (2016) and was used with the developer's permission (D. Applebaum, personal communications, July 1, 2020). The survey was used throughout the entire project.

The survey was administered using a paper form. Sound levels were recorded using a REED Instruments R8070SD Sound Level Meter. This meter had internal storage for data. 


\section{Missing Data and Data Storage}

Missing data were most likely missing at random (MAR). Pairwise deletion was the least biased way of treating MAR data and was used for missing data (Kang, 2013). All collected data were stored in cloud storage. The files were encrypted using Advanced Encryption Standard (AES) 256-bit encryption (Nechvatal et al., 2001). The encryption and cloud storage ensured redundancy as well as the security of the data.

\section{Evaluation Design}

Because sampling was by the convenience of the patients being discharged, there was no random sampling ability. The comparison group used primary data collected during the 6-weeks before implementing the noise reduction program. Descriptive statistics were used to describe the results of the project. Sound levels were analyzed, comparing baseline data with postintervention data using an independent t-test. Patient satisfaction with noise levels was analyzed using baseline and post-intervention data with an independent t-test. Statistical analysis of the data was performed using Intellectus Statistics.

\section{Categories of Measures}

Outcome measures were used to show the final results of the project. This included the satisfaction survey results and sound level measurements at the end of the 6-week implementation period. The process measure for this project was sound levels in the MSU. The balancing measures included ensuring that medication errors did not increase or an increase in missed monitor or IV pump alarms. The financial measure was ensuring that the project stays within budget. The sustainability measures will be implementing the intervention in other departments throughout the organization after the initial six weeks in the MSU. 


\section{Benchmarks}

WHO (2009) provided recommendations for noise levels in hospitals. These recommendations were used for setting the noise level benchmarks. The organization stives to achieve the highest satisfaction level. This led to the benchmarks for all satisfaction survey questions. These benchmarks are presented in Table 2.

\section{Table 2}

Benchmarks for the Project

\begin{tabular}{|c|c|c|}
\hline $\begin{array}{l}\text { Variable } \\
\text { Name }\end{array}$ & Variable Description & Benchmark \\
\hline Noise & Noise levels in the hospital & $\begin{array}{l}\text { Less than } 30 \mathrm{~dB} \text { at night } \\
\text { Less than } 35 \mathrm{~dB} \text { during the } \\
\text { day }\end{array}$ \\
\hline $\begin{array}{l}\text { Noise } \\
\text { satisfaction }\end{array}$ & $\begin{array}{l}\text { I was awakened at night by sounds during my } \\
\text { hospital stay, other than by a nurse for a } \\
\text { required activity }\end{array}$ & Strongly Agree \\
\hline $\begin{array}{l}\text { Noise } \\
\text { satisfaction }\end{array}$ & $\begin{array}{l}\text { My rest during the day was disturbed by } \\
\text { sounds during my hospital stay, other than by } \\
\text { a nurse for a required activity }\end{array}$ & Strongly Agree \\
\hline $\begin{array}{l}\text { Noise } \\
\text { satisfaction }\end{array}$ & I would rate my quality of sleep as acceptable & Strongly Agree \\
\hline $\begin{array}{l}\text { Noise } \\
\text { satisfaction }\end{array}$ & $\begin{array}{l}\text { I would rate my quantity (how much sleep I } \\
\text { got) of sleep as acceptable }\end{array}$ & Strongly Agree \\
\hline
\end{tabular}

\section{Tools}

Baseline noise levels were obtained before the intervention. Historical satisfaction scores with hospital noise were obtained from discharge surveys collected for 6 weeks before implementing the change project. Noise levels were continuously monitored using a permanently placed sound monitor using a calibrated REED Instruments R8070SD Sound Level Meter. This ensured that noise monitoring was valid and reliable. This data was continuous. 
Noise satisfaction scores were obtained with discharge surveys and indicated the patients' satisfaction with noise levels. The tool used was the Patient Survey on Noise During Hospital Stay, as seen in (Appendix E). This tool consisted of four items in a five-point Likert scale. The scale is: strongly agree, agree, neither, disagree, and strongly disagree. These four questions measured the patients' satisfaction with noise in the hospital. An additional five items using the same Likert scale were used to assess the quiet-time implementation's efficacy. Five questions were used to help identify sources and times of noises that disturb the patients. Additional questions included sex, age, and length of stay. No personal identifying information was collected. Reliability for the tool was determined by Cronbach $\alpha$ coefficient calculation and resulted in a coefficient of 0.60. The Patient Survey on Noise During Hospital Stay was administered using a paper form. The survey data was ordinal.

\section{Control for Extraneous Influences}

The MSU supervisor or house supervisor conducted daily reviews and walkthroughs to ensure that the noise reduction plan was implemented. Deviations from the plan will be corrected using just in time education of the staff and the reimplementation of the missing processes. This will also be reported to the project manager.

\section{Data Analysis}

\section{Patient Demographics}

The most frequently observed category of Gender was Female $(n=69,64 \%)$. Frequencies and percentages are presented in Table 3. 


\section{Table 3}

Frequency Table for Nominal Variables

\begin{tabular}{lll}
\hline Variable & $n$ & $\%$ \\
\hline Gender & & \\
Female & 69 & 63.89 \\
Male & 39 & 36.11 \\
\hline
\end{tabular}

The observations for Age had an average of $59.01\left(S D=14.89, S E_{M}=1.43, \operatorname{Min}=18.00\right.$, Max $=93.00$, Skewness $=-0.48$, Kurtosis $=0.01)$. The observations for Nights had an average of $2.56\left(S D=2.70, S E_{M}=0.26, \operatorname{Min}=1.00\right.$, Max $=17.00$, Skewness $=2.93$, Kurtosis $\left.=9.98\right)$. The summary statistics can be found in Table 4 .

\section{Table 4}

Summary Statistics Table for Interval and Ratio Variables

\begin{tabular}{lrrrrrrrr}
\hline Variable & $M$ & $S D$ & $n$ & $S E_{M}$ & Min & Max & Skewness & Kurtosis \\
\hline Age & 59.01 & 14.89 & 108 & 1.43 & 18.00 & 93.00 & -0.48 & 0.01 \\
Nights & 2.56 & 2.70 & 108 & 0.26 & 1.00 & 17.00 & 2.93 & 9.98 \\
\hline
\end{tabular}

\section{Awakened at Night by Sounds}

A two-tailed independent samples $t$-test was conducted to examine whether the mean of awakened at night by sounds was significantly different between the pre and post intervention categories. The result of the two-tailed independent samples $t$-test was not significant based on an alpha value of $0.05, t(103)=0.75, p=0.452$, indicating the null hypothesis cannot be rejected. This finding suggested the mean of awakened at night by sounds was not significantly different between the pre and post intervention categories. The results are presented in Table 5.

\section{Table 5}

Two-Tailed Independent Samples t-Test for Awakened at Night by Sounds by Pre or Post Intervention

\begin{tabular}{|c|c|c|c|c|c|c|c|}
\hline \multirow[b]{2}{*}{ Variable } & \multicolumn{2}{|c|}{ Pre } & \multicolumn{2}{|c|}{ Post } & \multirow[b]{2}{*}{$t$} & \multirow[b]{2}{*}{$p$} & \multirow[b]{2}{*}{$d$} \\
\hline & $M$ & $S D$ & $M$ & $S D$ & & & \\
\hline Awakened at night & 3.78 & 1.21 & 3.60 & 1.24 & 0.75 & 0.452 & 0.15 \\
\hline
\end{tabular}

Note. $\mathrm{N}=105$. Degrees of Freedom for the $t$-statistic $=103 . d$ represents Cohen's $d$. 


\section{Rest During the Day Disturbed by Sound}

A two-tailed independent samples $t$-test was conducted to examine whether the mean of rest during the day was disturbed by sounds was significantly different between the Pre and Post Intervention categories. The result of the two-tailed independent samples $t$-test was not significant based on an alpha value of $0.05, t(103)=-0.67, p=0.501$, indicating the null hypothesis cannot be rejected. This finding suggests the mean of rest during the day was disturbed by sounds was not significantly different between the pre and post intervention categories. The results are presented in Table 6.

\section{Table 6}

Two-Tailed Independent Samples t-Test for Rest During the Day Disturbed by Sounds by Pre or Post Intervention

\begin{tabular}{cccccccc}
\hline & \multicolumn{3}{c}{ Pre } & \multicolumn{2}{c}{ Post } & & \\
Variable & $M$ & $S D$ & $M$ & $S D$ & $T$ & $p$ & $d$ \\
\cline { 2 - 8 } Daytime Rest Disturbance & 3.59 & 1.22 & 3.76 & 1.18 & -0.67 & 0.501 & 0.14 \\
\hline
\end{tabular}

Note. $\mathrm{N}=105$. Degrees of Freedom for the $t$-statistic $=103 . d$ represents Cohen's $d$.

\section{Acceptable Sleep Quality}

A two-tailed independent samples $t$-test was conducted to examine whether the mean of acceptable sleep quality was significantly different between the pre and post intervention categories. The result of the two-tailed independent samples $t$-test was not significant based on an alpha value of $0.05, t(104)=-0.29, p=0.776$, indicating the null hypothesis cannot be rejected. This finding suggests the mean of acceptable sleep quality was not significantly different between the pre and post intervention categories. The results are presented in Table 7.

\section{Table 7}

Two-Tailed Independent Samples t-Test for Acceptable Sleep Quality by Pre or Post Intervention

\begin{tabular}{cccccccc}
\hline & \multicolumn{2}{c}{ Pre } & \multicolumn{2}{c}{ Post } & & & \\
\cline { 2 - 5 } Variable & $M$ & $S D$ & $M$ & $S D$ & $t$ & $p$ & $d$ \\
\hline Acceptable Sleep Quality & 3.85 & 0.95 & 3.90 & 0.81 & -0.29 & 0.776 & 0.06 \\
\hline
\end{tabular}

Note. $\mathrm{N}=106$. Degrees of Freedom for the $t$-statistic $=104 . d$ represents Cohen's $d$. 


\section{Acceptable Sleep Quality}

A two-tailed independent samples $t$-test was conducted to examine whether the mean of acceptable sleep quality was significantly different between the pre and post intervention categories. The result of the two-tailed independent samples $t$-test was not significant based on an alpha value of $0.05, t(102)=-0.54, p=0.591$, indicating the null hypothesis cannot be rejected. This finding suggests the mean of acceptable sleep quality was not significantly different between the Pre and Post Intervention categories. The results are presented in Table 8 .

\section{Table 8}

Two-Tailed Independent Samples t-Test for Acceptable Sleep Quantity by Pre or Post Intervention

\begin{tabular}{cccccccc}
\hline & \multicolumn{3}{c}{ Pre } & \multicolumn{2}{c}{ Post } & & \\
\cline { 2 - 7 } Variable & $M$ & $S D$ & $M$ & $S D$ & $T$ & $p$ & $d$ \\
\hline Acceptable Sleep Quantity & 3.77 & 0.95 & 3.87 & 0.92 & -0.54 & 0.591 & 0.11 \\
\hline
\end{tabular}

Note. $\mathrm{N}=104$. Degrees of Freedom for the $t$-statistic $=102 . d$ represents Cohen's $d$.

\section{Sound Analysis}

A two-tailed paired samples $t$-test was conducted to examine whether the mean difference of pre and post-intervention average noise levels was significantly different from zero. The result of the two-tailed paired samples $t$-test was significant based on an alpha value of $0.05, t(143)=$ $3.03, p=0.003$, indicating the null hypothesis can be rejected. This finding suggests the difference in the mean of pre and the mean of post-intervention average noise levels was significantly different from zero. The mean of pre-intervention average noise was significantly higher than the mean of post intervention average noise. The results are presented in Table 9.

\section{Table 9}

Two-Tailed Paired Samples t-Test for the Difference Between Pre and Post Intervention Average Noise Levels

\begin{tabular}{ccccccc}
\hline \multicolumn{2}{c}{ Pre } & \multicolumn{2}{c}{ Post } & & & \\
\cline { 1 - 4 }$M$ & $S D$ & $M$ & $S D$ & $t$ & 0.003 & 0.25 \\
\hline 49.68 & 1.97 & 49.58 & 1.73 & 3.03 &
\end{tabular}

Note. $\mathrm{N}=144$. Degrees of Freedom for the $t$-statistic $=143 . d$ represents Cohen's $d$. 


\section{Statistical and Clinical Significance}

During the intervention, a statistical decrease in measurable noise levels was expected. Any notable decrease in sound levels or increased patient satisfaction with noise will be of clinical significance.

The analysis showed a statistical decrease in average noise levels. The four questions dealing with patient satisfaction with noise did not show a statistical change. Sleep disturbances caused by noise at night showed a decrease in patient satisfaction. Patient rest during the day, as well as overall sleep quality and quantity, did show improvements. Because of the increase in patient satisfaction with noise in three areas and the statistical decrease in average noise levels, this project showed clinical significance.

\section{Human Rights and Privacy}

This project proposal was submitted to the University of St. Augustine for Health Sciences Nursing Evidence-Based Practice Project Review Council for review and approval. Once this approval was obtained, the project proposal was forwarded to the facility's chief nursing officer for final approval. This project had minimal risk to the patients as well as minimal risk of subject identification. The patients were surveyed with no patient identification information. The data collected was the patient's perception of noise and satisfaction with the noise levels. All data was stored in encrypted cloud storage. There were no conflicts of interest. There was no incentive given for participating in this project.

\section{Impact}

This project brought an awareness of noise to the facility staff and how it can impact patient satisfaction. Staff is aware of the noise that they generate and are cognizant of how they can help to reduce excess noise. Digital sound level displays were left in place for the staff to 
self-monitor the noise levels in the MSU. The visual feedback sound monitor remains installed. This gives management and staff a visual tool to help reenforce the need for noise reduction. HCAHPS scores will be reviewed periodically by management to measure progress and sustainability. These tools will help to make this a part of the everyday work culture in the MSU. To monitor the continued effectiveness of the project, HCAHPS scores for the patients' satisfaction with noise will need to be monitored for any changes.

During this project 108 patients were surveyed on their satisfaction with noise. Average noise levels showed a statistical decrease in noise levels. This decrease and the implementation of the noise reduction program produced a clinically significant increase in patient satisfaction with noise during the day. There was also an increase of patient satisfaction with both the quality and quantity of sleep.

Limitations to this project included the facility's response to COVID-19. There were strict limitations on visitors to the MSU. This limitation decreased both the baseline and postintervention noise levels. To support other areas of the facility with the care of COID-19 patients, part of the MSU was periodically reassigned to the PCU for higher acuity patients. The PCU staff was not part of this project. The facility was implementing a change to reduce patient falls. This change included an increase in the use of bed alarms. The main hallway in the MSU is the primary employee entrance to the facility. The placement of the bed alarms and the employee through traffic contributed to noise levels that could not be controlled by this project.

\section{Plans for Dissemination}

Due to the COVID-19 pandemic, the project results were presented through virtual meetings utilizing GoToMeeting with a PowerPoint. The results of this project were presented to the CLT. 
There are two organizations in Nebraska where the findings of this project will be presented. The Nebraska Hospital Association sponsors a quality improvement conference twice a year. One is the eastern part of the state, and the other is in the western region. This presentation will be submitted for presentation at both conferences. The other organization is the Nebraska Association of Healthcare Quality, Risk, and Safety. This organization meets every other month, and the project will be submitted for presentation at one of these meetings.

An abstract will be submitted to the National Association of Healthcare Quality (NAHQ) for consideration as a presenter for their annual conference. If the presentation is not accepted, then a separate application will be submitted for a poster presentation at the same conference. NAHQ was chosen because it is the leading professional organization for healthcare quality.

Publication is planned in the Journal of Healthcare Quality. This journal is the official journal of NAHQ. This will provide for the broadest dissemination among the healthcare quality community. The journal is peer-reviewed and has an internal peer-review process.

This evidence-based project will be submitted to the Scholarship and Open Access Repository website at the University of St. Augustine for Health Sciences (SOAR@USA). To contribute to wider dissemination, the project will also be submitted to ProQuest.

\section{Conclusion}

The goal of the noise reduction project was to improve the patients' overall satisfaction with hospital noise during the day and overnight. The ultimate goal was to improve the HCAHPS score for noise outside of the patients' room at night. This score is reported by CMS and is readily accessible by the public.

This paper described a project for a noise reduction program to improve satisfaction with noise for acute care patients. The project started with a discussion on the significance of the 
problem and addressed the PICOT question. The change theory and framework were discussed, a review of the literature was conducted, as was an overview of the theme(s) identified in the literature. From the theme(s), a practice recommendation was developed. The project setting and plan were described and included the method, evaluation, and sustainability of the project. 


\section{References}

Adatia, S., Law, S., \& Haggerty, J. (2014). Room for improvement: Noise on a maternity ward. BMC Health Services Research, 14(1), 604. https://doi.org/10.1186/s12913-014-0604-3

Applebaum, D., Calo, O., \& Neville, K. (2016). Implementation of quiet time for noise reduction on a medical-surgical unit. Journal of Nursing Administration, 46(12), 669-674. https://doi.org/10.1097/NNA.0000000000000424

Berglund, B., Lindvall, T., \& Schwela, D. H. (1999). Guidelines for community noise. World Health Organization. https://apps.who.int/iris/handle/10665/66217

Center for Disease Control and Prevention. (2019). Loud noise can cause hearing loss. https://www.cdc.gov/nceh/hearing_loss/what_noises_cause_hearing_loss.html

Center for Hearing and Communication. (n.d.). Common environmental noise levels. https://chchearing.org/noise/common-environmental-noise-levels/

Centers for Medicare and Medicaid Services. (n.d.-a). HCAHPS: Patients' perspectives of care survey. https://www.cms.gov/Medicare/Quality-Initiatives-Patient-AssessmentInstruments/HospitalQualityInits/HospitalHCAHPS

Centers for Medicare and Medicaid Services. (n.d.-b). Hospital compare. https://www.medicare.gov/hospitalcompare/search.html?

Christofel, H. K., Madeiras, J. G., Bertolini, S. M. M. G., \& de Oliveira, J. M. (2016). Noise level analysis in adult intensive care unit. Revista Da Rede de Enfermagem Do Nordeste, 17(4), 553-0560. https://doi.org/10.15253/2175-6783.2016000400016

Clark, A., \& Mills, M. (2017). Can a sleep menu enhance the quality of sleep for the hospitalized patient? MEDSURG Nursing, 26(4), 253-257. http://prxusa.lirn.net/login?url=http://search.ebscohost.com/login.aspx?direct=true $\& \mathrm{db}=\mathrm{ccm} \& \mathrm{AN}=1$ 


\section{$\underline{24650212 \& \text { site }=\text { eds-live }}$}

Dang, D., \& Dearholt, S. L. (2018). Johns Hopkins nursing evidence-based practice: Model and guidelines (3rd ed.). Sigma Theta Tau International.

Delaney, L. J., Currie, M. J., Huang, H.-C. C., Lopez, V., Litton, E., \& Van Haren, F. (2017). The nocturnal acoustical intensity of the intensive care environment: An observational study. Journal of Intensive Care, 5(41), 1-8. https://doi.org/10.0.4.162/s40560-017-0237-9

Delaney, L. J., Currie, M. J., Huang, H.-C. C., Lopez, V., \& Van Haren, F. (2018). “They can rest at home": An observational study of patients' quality of sleep in an Australian hospital. BMC Health Services Research, 18(524), 1-9. https://doi.org/10.1186/s12913-018-3201-z

Duss, S. B., Seiler, A., Schmidt, M. H., Pace, M., Adamantidis, A., Müri, R. M., \& Bassetti, C. L. (2017). The role of sleep in recovery following ischemic stroke: A review of human and animal data. Neurobiology of Sleep and Circadian Rhythms, 2, 94-105. https://doi.org/10.1016/j.nbscr.2016.11.003

Graham, I. D., Logan, J., Harrison, M. B., Straus, S. E., Tetroe, J., Caswell, W., \& Robinson, N. (2006). Lost in knowledge translation: Time for a map? The Journal of Continuing Education in the Health Professions, 26(1), 13-24. https://doi.org/10.1002/chp.47

Gulam, S., Xyrichis, A., \& Lee, G. A. (2020). Still too noisy - An audit of sleep quality in trauma and orthopaedic patients. International Emergency Nursing, 49, 1-6. http://10.0.3.248/j.ienj.2019.100812

Kang, H. (2013). The prevention and handling of the missing data. Korean Journal of Anesthesiology, 64(5), 402-406. https://doi.org/10.4097/kjae.2013.64.5.402

Kaur, H., Rohlik, G. M., Nemergut, M. E., \& Tripathi, S. (2016). Comparison of staff and family perceptions of causes of noise pollution in the pediatric intensive care unit and suggested 
intervention strategies. Noise and Health, 18(81), 78-84. https://doi.org/10.4103/1463-

$\underline{1741.178480}$

MacKay, P., Ruhlen, T., Crow, P., Hughes, J., Pfeiffer, K., \& Hagler, K. (2019). The effect of a quiet environment on the comfort of post-operative infants and young children. Pediatric Nursing, 45(5), 244-249. http://www.pediatricnursing.net/

Moher, D., Liberati, A., Tetzlaff, J., \& Altman, D. G. (2009). Preferred reporting items for systematic reviews and meta-analyses: The PRISMA statement. Journal of Clinical Epidemiology, 62(10), 1006-1012. https://doi.org/10.1016/j.jclinepi.2009.06.005

Mutair, A. Al, Shamsan, A., AlFaqiri, A., \& Al-Omari, A. (2019). Intensive care unit patients' perception of sleep quality and factors of sleep disruption: Cross-sectional study. Dr. Sulaiman Al Habib Medical Journal, 1(30-35). https://doi.org/10.2991/dsahmj.k.190530.001

Nechvatal, J., Barker, E., Bassham, L., Burr, W., Dworkin, M., Foti, J., \& Roback, E. (2001). Report on the development of the Advanced Encryption Standard (AES). Journal of Research of the National Institute of Standards and Technology, 106(3), 511-577. https://doi.org/10.6028/jres.106.023

Nightingale, F. (1860). Notes on nursing: What it is, and what it is not. D. Appleton and Company. http://digital.library.upenn.edu/women/nightingale/nursing/nursing.html

Rice, M. J. (2010). Evidence-based practice problems: Form and focus. Journal of the American Psychiatric Nurses Association, 16(5), 307-314. https://doi.org/10.1177/1078390310374990

Ryan, K. M., Gagnon, M., Hanna, T., Mello, B., Fofana, M., Ciottone, G., \& Molloy, M. (2016). Noise pollution: Do we need a solution? An analysis of noise in a cardiac care unit. 
Prehospital \& Disaster Medicine, 31(4), 432-435. https://doi.org/10.1017/S1049023X16000388

Society for Human Resource Management. (2015). Understanding organizational structures. https://www.shrm.org/resourcesandtools/tools-and$\underline{\text { samples/toolkits/pages/understandingorganizationalstructures.aspx }}$

Steaphen, A., Olson, D. M., \& Stutzman, S. E. (2017). Nurses perceptions of a novel protocol addressing uniform periods of minimum assessment times. Journal of Neuroscience Nursing, 49(5), 302-306. https://doi.org/10.1097/JNN.0000000000000311

Stewart, N. H., \& Arora, V. M. (2018). Sleep in hospitalized older adults. Sleep Medicine Clinics, 13(1), 127-135. https://doi.org/10.1016/j.jsmc.2017.09.012

Stickland, A., Clayton, E., Sankey, R., \& Hill, C. M. (2016). A qualitative study of sleep quality in children and their resident parents when in hospital. Archives of Disease in Childhood, 101(6), 546-551. https://doi.org/10.1136/archdischild-2015-309458

Stremler, R., Adams, S., \& Dryden-Palmer, K. (2015). Nurses' views of factors affecting sleep for hospitalized children and their families: A focus group study. Research in Nursing \& Health, 38(4), 311-322. https://doi.org/10.1002/nur.21664

Tabas, E. E., Khodadadi, F., Sarani, H., Saeedinezhad, F., \& Jahantigh, M. (2019). Effect of eye masks, earplugs, and quiet time protocol on sleep quality of patients admitted to the cardiac care unit: A clinical trial study. Medical-Surgical Nursing Journal, 8(3), 1-6. https://doi.org/10.5812/msnj.98762

Waller-Wise, R., \& Mad, B. L. M. (2019). Implementing a quiet time intervention in a labordelivery-recovery-postpartum unit. International Journal of Childbirth Education, 34(1), 27-31. https://icea.org/ 
White, K. M. (2016). Change theory and models: Framework for translation. In K. M. White, S. Dudley-Brown, \& M. F. Terhaar (Eds.), Translation of evidence into nursing practice (2nd ed., pp. 57-70). Springer Publishing.

World Health Organization. (2009). Night noise guidelines for Europe. https://www.euro.who.int/_data/assets/pdf_file/0017/43316/E92845.pdf

Younis, M. B., Hayajneh, F., \& Rubbai, Y. (2020). Factors influencing sleep quality among Jordanian intensive care patients. British Journal of Nursing (Mark Allen Publishing), 29(5), 298-302. https://doi.org/10.12968/bjon.2020.29.5.298

Zamani, K., Asgharnia, H. A., Yazdani, J., \& Taraghi, Z. (2018). The effect of staff training on the amount of sound pollution in the intensive care unit. Journal of Nursing \& Midwifery Sciences, 5(5), 130-133. https://doi.org/10.4103/JNMS.JNMS_38_18

Zhang, J., Xu, D., Xie, B., Zhang, Y., Huang, H., Liu, H., Chen, H., Sun, Y., Shang, Y., Hashimoto, K., \& Yuan, S. (2020). Poor-sleep is associated with slow recovery from lymphopenia and an increased need for ICU care in hospitalized patients with COVID-19: A retrospective cohort study. Brain, Behavior, and Immunity, 88(May), 50-58. https://doi.org/10.1016/j.bbi.2020.05.075 


\section{Figure 1}

Knowledge to Action Process

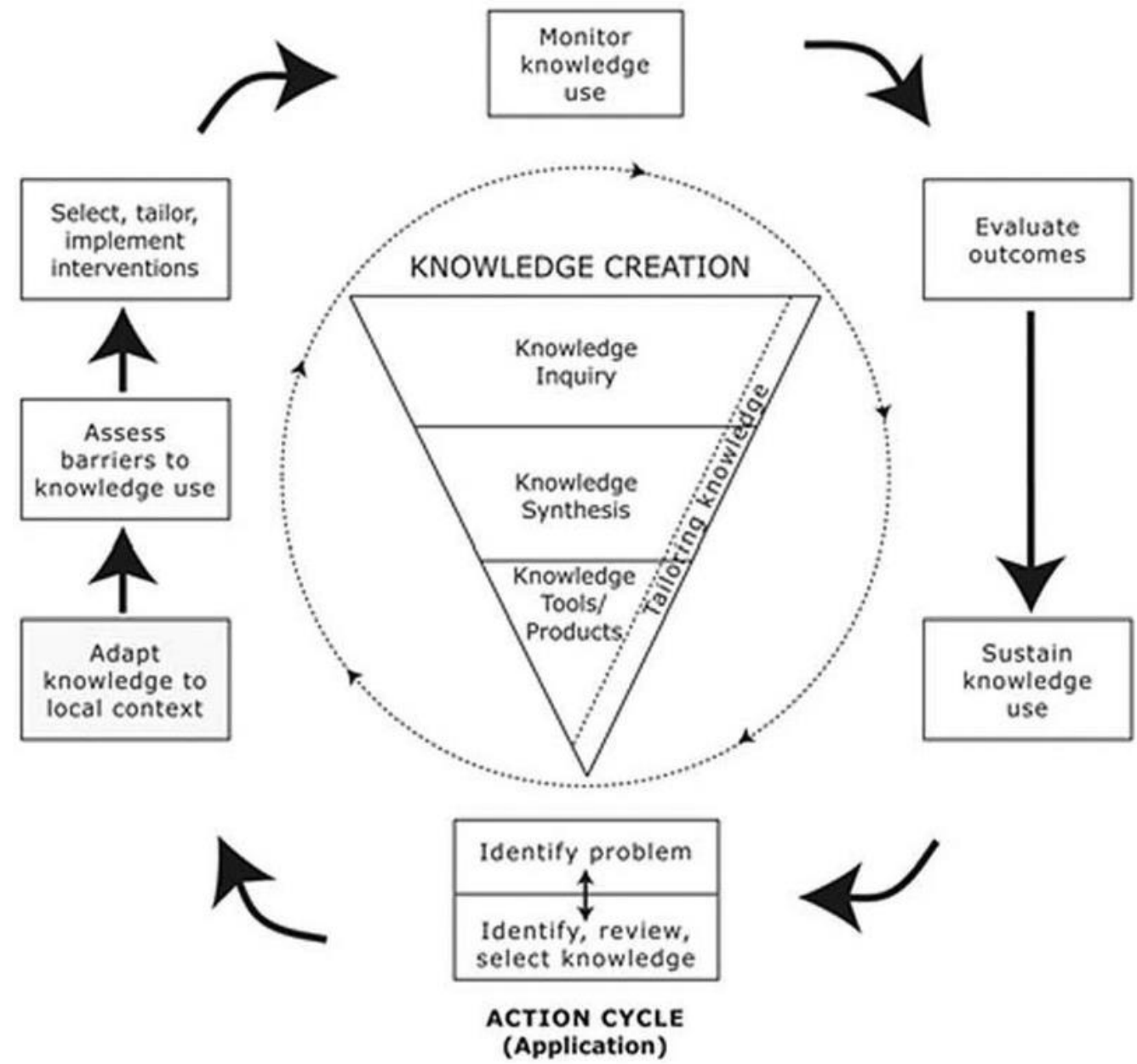

Note. Knowledge to action process diagram. From "Lost in Knowledge Translation: Time for a Map?” by I. D. Graham, J. Logan, M. B. Harrison, S. E. Straus, J. Tetroe, W. Caswell, and N. Robinson, 2006, The Journal of Continuing Education in the Health Professions, 26(1), p. 19 (https://doi.org/10.1002/chp.47). Copyright 2006 by John Wiley \& Son. Reprinted with permission (see Appendix A). 
Figure 2

PRISMA Flow Diagram

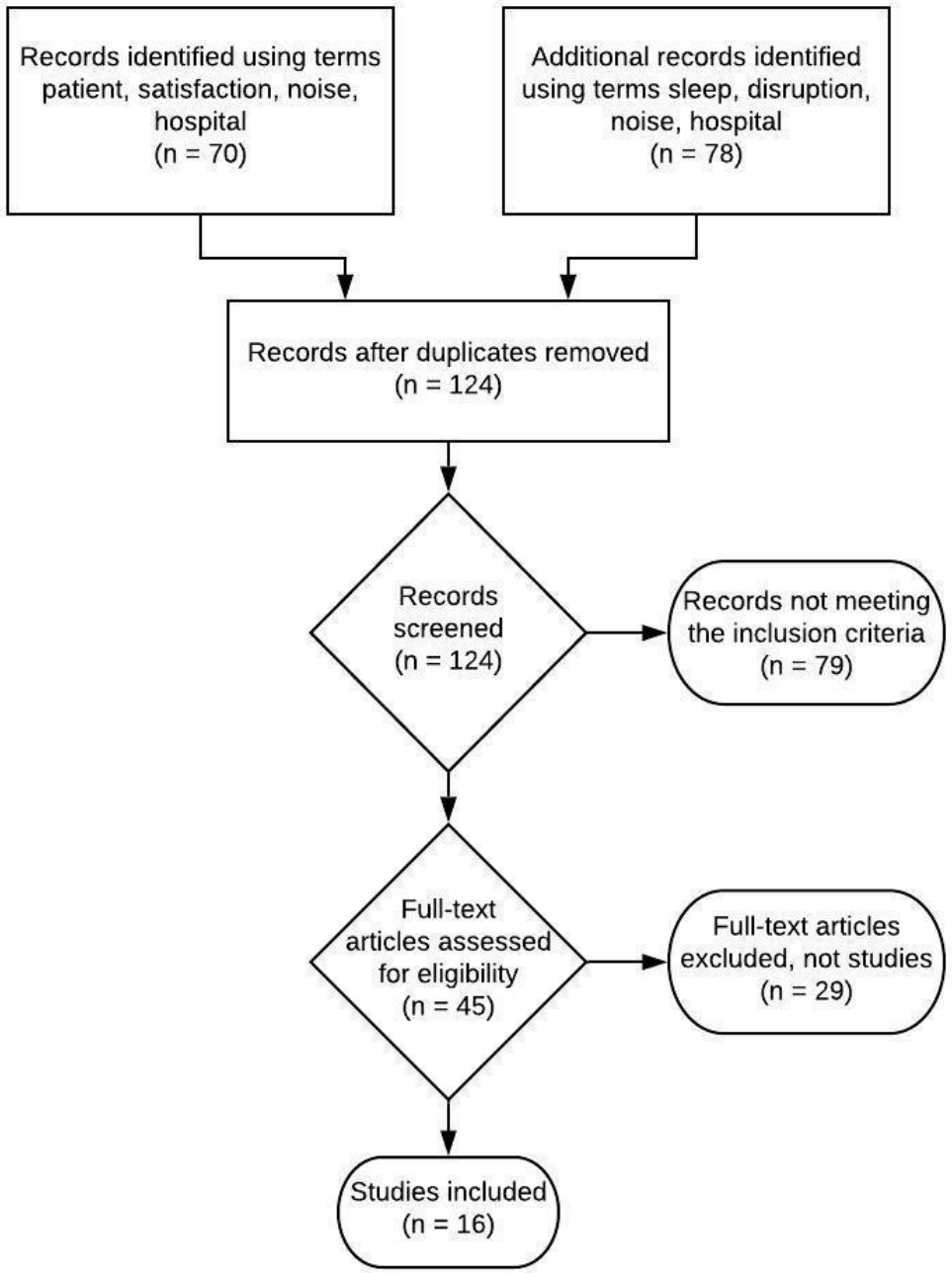

Note. Prisma flow diagram. Adapted from "Preferred Reporting Items for Systematic Reviews and Meta-Analyses: The PRISMA Statement," by D. Moher, A. Liberati, J. Tetzlaff, and D. G. Altman, 2009, Journal of Clinical Epidemiology,62(10), p. 1009

(https://doi.org/10.1016/j.jclinepi.2009.06.005). Copyright 2009 by Elsevier Publishing Company. 


\section{Appendix A}

\section{Copyright Permission for the Knowledge to Action Process Diagram}

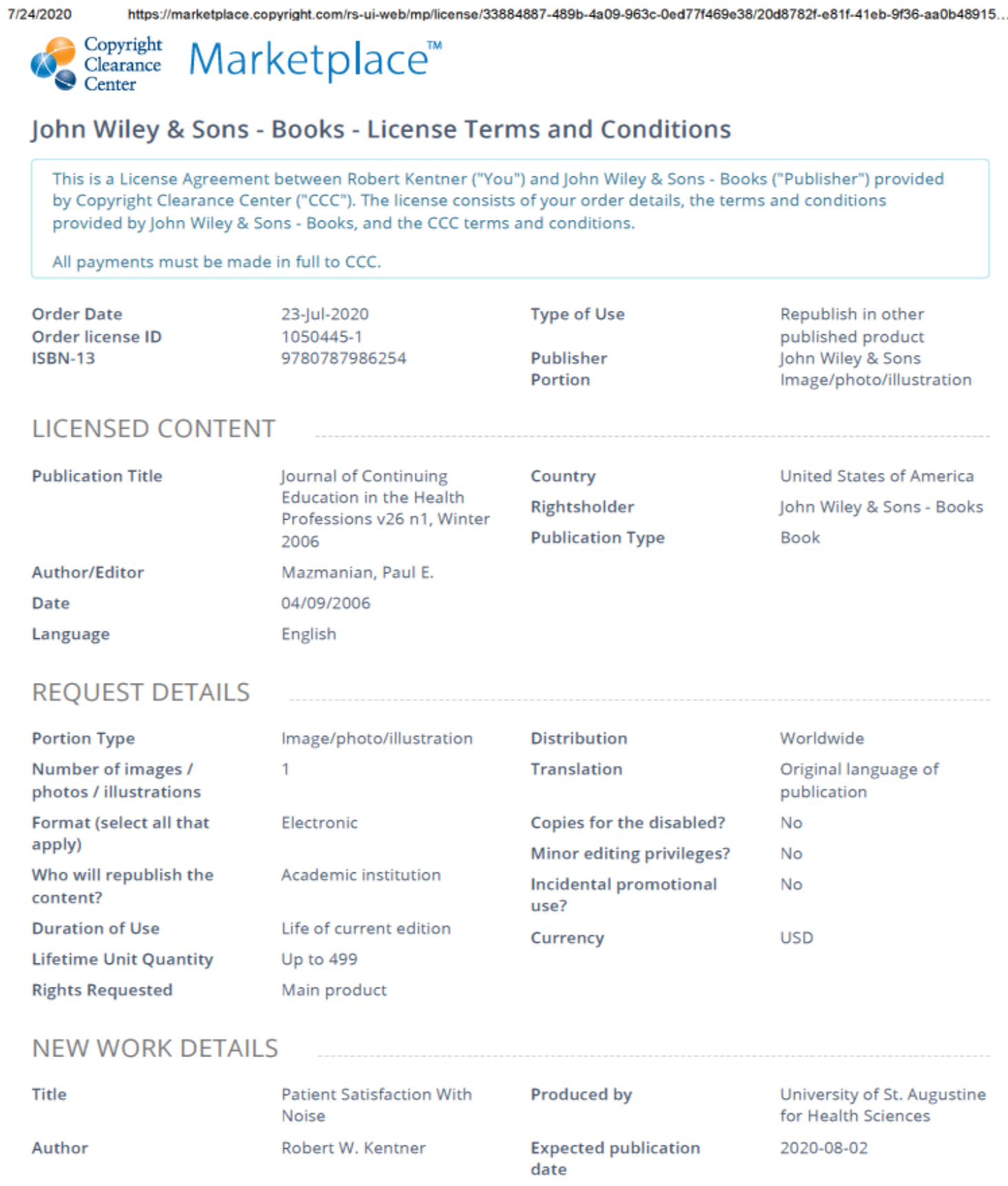

\section{ADDITIONAL DETAILS}

Order reference number N/A
The requesting person /
Robert Kentner
organization to appear
on the license

https://marketplace copyright.com/rs-ui-web/mp/license/33884887-489b-4a09-963c-0ed77f469e38/20d8782f-e81f-41eb-9f36-aa0b4891529d 


\section{Appendix B}

Summary of Primary Research Evidence

\begin{tabular}{|c|c|c|c|c|c|c|}
\hline Citation & $\begin{array}{l}\text { Design, } \\
\text { Level } \\
\text { Quality } \\
\text { Grade }\end{array}$ & $\begin{array}{c}\text { Sample } \\
\text { Sample size }\end{array}$ & $\begin{array}{c}\text { Intervention } \\
\text { Comparison } \\
\text { (Definitions } \\
\text { should include } \\
\text { any specific } \\
\text { research tools } \\
\text { used along with } \\
\text { reliability \& } \\
\text { validity) } \\
\end{array}$ & $\begin{array}{l}\text { Theoretical } \\
\text { Foundation }\end{array}$ & $\begin{array}{l}\text { Outcome } \\
\text { Definition }\end{array}$ & $\begin{array}{l}\text { Usefulness } \\
\text { Results } \\
\text { Key Findings }\end{array}$ \\
\hline $\begin{array}{l}\text { Applebaum et al., } \\
\text { (2016). }\end{array}$ & II-B & $\begin{array}{l}\text { A convenience sample was } \\
\text { obtained from volunteer } \\
\text { patients. } \\
\mathrm{n}=80 \\
\mathrm{n}=40 \text { control group, } \mathrm{n}=40 \\
\text { intervention group }\end{array}$ & $\begin{array}{l}\text { The intervention } \\
\text { is the } \\
\text { implementation } \\
\text { of a 1-hour } \\
\text { quiet-time from } \\
1400-1500 \text { daily. } \\
\text { The comparison } \\
\text { is no quiet- } \\
\text { times. } \\
\text { The study used } \\
\text { the "Patient } \\
\text { Survey on Noise } \\
\text { During Hospital } \\
\text { Stay" tool. }\end{array}$ & $\begin{array}{l}\text { Florence } \\
\text { Nightingale's } \\
\text { statement on } \\
\text { the } \\
\text { detrimental } \\
\text { effects of } \\
\text { noise for } \\
\text { patients. }\end{array}$ & $\begin{array}{l}\text { The } \\
\text { effectiveness } \\
\text { of quiet-time } \\
\text { on patient } \\
\text { perception of } \\
\text { noise }\end{array}$ & $\begin{array}{l}\text { Quiet-time is } \\
\text { effective in } \\
\text { improving patient } \\
\text { perception of } \\
\text { noise. }\end{array}$ \\
\hline Christofel et al., (2016). & II-C & $\begin{array}{l}\text { A convenience sample of } \\
\text { everyone working on the ICU } \\
\text { during the study } \\
\mathrm{N}=35\end{array}$ & $\begin{array}{l}\text { The intervention } \\
\text { was the } \\
\text { adjustment of } \\
\text { ventilator alarm } \\
\text { volumes and } \\
\text { settings. }\end{array}$ & $\begin{array}{l}\text { No } \\
\text { theoretical } \\
\text { foundation } \\
\text { was stated }\end{array}$ & $\begin{array}{l}\text { The outcome } \\
\text { definition was } \\
\text { not clear }\end{array}$ & $\begin{array}{l}\text { Reducing } \\
\text { ventilator alarm } \\
\text { volumes reduces } \\
\text { noise in the } \\
\text { intensive care } \\
\text { unit. }\end{array}$ \\
\hline
\end{tabular}




\begin{tabular}{|c|c|c|c|c|c|c|}
\hline & & & $\begin{array}{l}\text { The comparison } \\
\text { was no } \\
\text { adjustment of } \\
\text { alarm volumes. } \\
\text { Tools used were } \\
\text { sound } \\
\text { measurement } \\
\text { devices and a } \\
\text { locally } \\
\text { published } \\
\text { questionnaire }\end{array}$ & & & \\
\hline Clark and Mills (2017). & $\mathrm{I}-\mathrm{A}$ & $\begin{array}{c}\text { Convenience sample of patients } \\
\text { in the medical-surgical unit } \\
\quad \mathrm{N}=62 \\
\mathrm{n}=31 \text { control group, } \mathrm{n}=31 \\
\text { intervention group }\end{array}$ & $\begin{array}{l}\text { The intervention } \\
\text { is the use of a } \\
\text { sleep menu to } \\
\text { identify and } \\
\text { implement } \\
\text { patient } \\
\text { preferences on } \\
\text { sleep time ritual. } \\
\text { The control } \\
\text { group did not } \\
\text { have a sleep } \\
\text { time menu } \\
\text { The specific tool } \\
\text { used was a sleep } \\
\text { time menu } \\
\text { created locally } \\
\text { to help the } \\
\text { patient } \\
\text { communicate } \\
\text { sleep time } \\
\text { preferences. } \\
\text { iRounds survey } \\
\text { tool was used to } \\
\text { capture patient } \\
\text { feedback. }\end{array}$ & $\begin{array}{l}\text { No } \\
\text { theoretical } \\
\text { foundation } \\
\text { was stated }\end{array}$ & $\begin{array}{l}\text { The outcome } \\
\text { was defined as } \\
\text { implementing a } \\
\text { sleep menu } \\
\text { improved } \\
\text { patient rest and } \\
\text { satisfaction } \\
\text { with sleep }\end{array}$ & $\begin{array}{l}\text { The patient sleep } \\
\text { menu provides a } \\
\text { tool to improve } \\
\text { patient } \\
\text { satisfaction with } \\
\text { sleep. }\end{array}$ \\
\hline
\end{tabular}




\begin{tabular}{|c|c|c|c|c|c|c|}
\hline Delaney et al., (2017). & III-C & $\begin{array}{c}\text { An observational cross-sectional } \\
\text { study of noise. There were no } \\
\text { study participants. }\end{array}$ & $\begin{array}{l}\text { The study } \\
\text { determined } \\
\text { noise levels and } \\
\text { causes at night. } \\
\text { Researchers } \\
\text { observed and } \\
\text { recorded causes } \\
\text { of noise. Noise } \\
\text { levels were } \\
\text { recorded to } \\
\text { determine the } \\
\text { minimum, } \\
\text { maximum, and } \\
\text { mean noise } \\
\text { levels overnight. }\end{array}$ & $\begin{array}{l}\text { No } \\
\text { theoretical } \\
\text { foundation } \\
\text { was stated }\end{array}$ & $\begin{array}{l}\text { Identification } \\
\text { of possible } \\
\text { causes of } \\
\text { excess noise }\end{array}$ & $\begin{array}{l}\text { Noise levels } \\
\text { exceeded World } \\
\text { Health } \\
\text { Organization } \\
\text { (WHO) } \\
\text { recommendations }\end{array}$ \\
\hline Delaney et al., (2018). & II-B & $\begin{array}{l}\text { Non-probability convenience } \\
\text { sample } \\
n=144\end{array}$ & $\begin{array}{l}\text { The intervention } \\
\text { was sleep } \\
\text { quality in a } \\
\text { hospital. } \\
\text { The control was } \\
\text { sleep quality at } \\
\text { home. } \\
\text { Tool used was } \\
\text { survey on sleep } \\
\text { quality. This } \\
\text { study compared } \\
\text { the quality of } \\
\text { sleep patients } \\
\text { experienced in } \\
\text { the hospital to } \\
\text { reported quality } \\
\text { of sleep at home. }\end{array}$ & $\begin{array}{l}\text { No } \\
\text { theoretical } \\
\text { foundation } \\
\text { was stated }\end{array}$ & $\begin{array}{l}\text { The study was } \\
\text { to determine if } \\
\text { sleep quality } \\
\text { decreased in } \\
\text { hospitals as } \\
\text { compared to at } \\
\text { home. }\end{array}$ & $\begin{array}{l}\text { Noise was } \\
\text { identified as one } \\
\text { of the primary } \\
\text { factors in sleep } \\
\text { disturbance. }\end{array}$ \\
\hline Gulam et al., (2020). & III-B & $\begin{array}{c}\text { Convenience sample of patients } \\
\text { with a minimum of a } 2 \text { day } \\
\text { inpatient stay } \\
n=40\end{array}$ & $\begin{array}{l}\text { This study } \\
\text { provided a } \\
\text { snapshot of } \\
\text { patient's }\end{array}$ & $\begin{array}{l}\text { No } \\
\text { theoretical } \\
\text { foundation } \\
\text { was stated }\end{array}$ & $\begin{array}{l}\text { Sleep quality } \\
\text { of trauma and } \\
\text { orthopedic } \\
\text { patients }\end{array}$ & $\begin{array}{l}\text { Study showed } \\
\text { perceived sleep } \\
\text { quality as poor } \\
\text { but did not }\end{array}$ \\
\hline
\end{tabular}




\begin{tabular}{|c|c|c|c|c|c|c|}
\hline & & & $\begin{array}{l}\text { perception of } \\
\text { sleep. No } \\
\text { interventions } \\
\text { were performed. }\end{array}$ & & & $\begin{array}{l}\text { identify specific } \\
\text { causes or } \\
\text { changes. }\end{array}$ \\
\hline Kaur et al., (2016). & III-B & $\begin{array}{l}\text { A convenience sample of all } \\
\text { PICU staff and patients that } \\
\text { spent more than } 24 \text { hours in the } \\
\text { PICU } \\
\text { Patient } n=50 \\
\text { Staff } n=65\end{array}$ & $\begin{array}{l}\text { No interventions } \\
\text { were performed. } \\
\text { Subjective data } \\
\text { was collected on } \\
\text { causes of noise. } \\
\text { A locally } \\
\text { developed } \\
\text { questionnaire } \\
\text { was used in this } \\
\text { study }\end{array}$ & $\begin{array}{l}\text { No } \\
\text { theoretical } \\
\text { foundation } \\
\text { was stated }\end{array}$ & $\begin{array}{l}\text { Determine } \\
\text { perceived } \\
\text { causes of } \\
\text { excess noise. }\end{array}$ & $\begin{array}{l}\text { Closing the doors } \\
\text { was listed as the } \\
\text { top intervention } \\
\text { for reducing noise } \\
\text { in patients' rooms }\end{array}$ \\
\hline MacKay et al., (2019). & I-B & $\begin{array}{l}\text { Convenience sample of } \mathrm{n}=33 \\
\text { Study groups were assigned by } \\
\text { room number, Odd numbers } \\
\text { were the intervention, even } \\
\text { numbers were the control. } \\
\mathrm{n}=17 \text { control group, } \mathrm{n}=16 \\
\text { intervention group }\end{array}$ & $\begin{array}{l}\text { The intervention } \\
\text { was placing } \\
\text { patients in } \\
\text { designated } \\
\text { quiet-rooms. } \\
\text { The control was } \\
\text { the use of } \\
\text { normal rooms. } \\
\text { Face, Legs, } \\
\text { Activity, Cry, } \\
\text { Consolability } \\
\text { pain scale and } \\
\text { sound level } \\
\text { meters were } \\
\text { used as tools for } \\
\text { this study }\end{array}$ & $\begin{array}{l}\text { Kocalba's } \\
\text { comfort } \\
\text { theory was } \\
\text { used as the } \\
\text { framework }\end{array}$ & $\begin{array}{l}\text { Patient's } \\
\text { comfort would } \\
\text { increase as } \\
\text { noise levels } \\
\text { decreased }\end{array}$ & $\begin{array}{l}\text { The use of quiet- } \\
\text { rooms produced } \\
\text { no change in } \\
\text { patient comfort } \\
\text { levels in infants } \\
\text { and young } \\
\text { children. }\end{array}$ \\
\hline Mutair et al., (2019). & III-B & $\begin{array}{l}\text { A convenience sample of ICU } \\
\text { patients that are alert and } \\
\text { oriented to person and place } \\
n=30\end{array}$ & $\begin{array}{l}\text { No interventions } \\
\text { were performed. } \\
\text { A questionnaire } \\
\text { was developed } \\
\text { to determine } \\
\text { patients sleep }\end{array}$ & $\begin{array}{l}\text { No } \\
\text { theoretical } \\
\text { foundation } \\
\text { was stated }\end{array}$ & $\begin{array}{l}\text { Determining } \\
\text { the causes of } \\
\text { sleep } \\
\text { disturbances } \\
\text { for ICU } \\
\text { patients }\end{array}$ & $\begin{array}{l}\text { Pain was the } \\
\text { leading factor in } \\
\text { sleep disturbance } \\
\text { followed by noise }\end{array}$ \\
\hline
\end{tabular}




\begin{tabular}{|c|c|c|c|c|c|c|}
\hline & & & $\begin{array}{l}\text { quality and } \\
\text { causes of } \\
\text { disruption for } \\
\text { ICU patients. }\end{array}$ & & & \\
\hline Ryan et al., (2016). & III-B & $\begin{array}{l}\text { An observational cross-sectional } \\
\text { study of noise. There were no } \\
\text { study participants. }\end{array}$ & $\begin{array}{l}\text { No intervention } \\
\text { was performed. } \\
\text { Sound levels } \\
\text { were recorded in } \\
\text { ICU patient } \\
\text { rooms and } \\
\text { hallways. The } \\
\text { study } \\
\text { determined } \\
\text { ambient noise } \\
\text { levels in the ICU } \\
\text { and compared } \\
\text { them to WHO } \\
\text { standards. }\end{array}$ & $\begin{array}{l}\text { No } \\
\text { theoretical } \\
\text { foundation } \\
\text { was stated }\end{array}$ & $\begin{array}{l}\text { Determine } \\
\text { sound levels in } \\
\text { patient rooms } \\
\text { and compare } \\
\text { them to the } \\
\text { WHO } \\
\text { recommendatio } \\
\text { ns. }\end{array}$ & $\begin{array}{l}\text { Sound levels } \\
\text { exceeded WHO } \\
\text { recommendations }\end{array}$ \\
\hline Stickland et al., (2016). & III-B & $\begin{array}{l}\text { Sampling was a convenience } \\
\text { sample of parents co-sleeping } \\
\text { with pediatric patients } \\
n=17\end{array}$ & $\begin{array}{l}\text { No intervention } \\
\text { was performed. } \\
\text { Parents were } \\
\text { interviewed to } \\
\text { determine their } \\
\text { perception of } \\
\text { causes for sleep } \\
\text { disturbances }\end{array}$ & $\begin{array}{l}\text { No } \\
\text { theoretical } \\
\text { foundation } \\
\text { was stated }\end{array}$ & $\begin{array}{l}\text { Determine } \\
\text { possible causes } \\
\text { of sleep } \\
\text { disturbances as } \\
\text { perceived buy } \\
\text { the nurses }\end{array}$ & $\begin{array}{l}\text { Implementation } \\
\text { of noise reduction } \\
\text { and patient } \\
\text { suggestions }\end{array}$ \\
\hline Stremler et al., (2015). & III-C & $\begin{array}{l}\text { A purposive sampling strategy } \\
\qquad \mathrm{n}=30\end{array}$ & $\begin{array}{l}\text { No intervention } \\
\text { was performed. } \\
\text { Staff nurses } \\
\text { were } \\
\text { interviewed to } \\
\text { determine their } \\
\text { perception of } \\
\text { causes for sleep } \\
\text { disturbances }\end{array}$ & $\begin{array}{l}\text { No } \\
\text { theoretical } \\
\text { foundation } \\
\text { was stated }\end{array}$ & $\begin{array}{l}\text { Determine } \\
\text { possible causes } \\
\text { of sleep } \\
\text { disturbances as } \\
\text { perceived buy } \\
\text { the nurses }\end{array}$ & $\begin{array}{l}\text { No clear take- } \\
\text { away from this } \\
\text { study }\end{array}$ \\
\hline
\end{tabular}




\begin{tabular}{|c|c|c|c|c|c|c|}
\hline Tabas et al., (2019). & II-A & $\begin{array}{l}\text { A convenience sample of } \\
\text { eligible ICU patients } \\
\qquad n=135 \\
\mathrm{n}=45 \text { control group, } \mathrm{n}=45 \\
\text { intervention group, second } \\
\text { intervention group } \mathrm{n}=45\end{array}$ & $\begin{array}{l}\text { Two different } \\
\text { interventions } \\
\text { were used. The } \\
\text { first was the } \\
\text { implementation } \\
\text { of quiet-time } \\
\text { protocols. The } \\
\text { second } \\
\text { intervention was } \\
\text { the use of eye } \\
\text { masks and ear } \\
\text { plugs. } \\
\text { The control } \\
\text { group did not } \\
\text { have quiet-time } \\
\text { or masks and } \\
\text { plugs. }\end{array}$ & $\begin{array}{l}\text { No } \\
\text { theoretical } \\
\text { foundation } \\
\text { was stated }\end{array}$ & $\begin{array}{l}\text { Determine if } \\
\text { eye masks and } \\
\text { ear plugs or } \\
\text { quiet-time } \\
\text { protocols } \\
\text { improve sleep } \\
\text { quality }\end{array}$ & $\begin{array}{l}\text { Both the quiet- } \\
\text { time protocol and } \\
\text { the use of eye } \\
\text { masks and ear } \\
\text { plugs both } \\
\text { showed } \\
\text { significant } \\
\text { improvement in } \\
\text { sleep quality }\end{array}$ \\
\hline $\begin{array}{l}\text { Waller-Wise and Mad } \\
\text { (2019). }\end{array}$ & II-A & $\begin{array}{l}\text { Convenience sampling of } \\
\text { patients in the labor-delivery- } \\
\text { recovery-postpartum unit. } \\
\mathrm{n}=131 \\
\mathrm{n}=67 \text { control group, } \mathrm{n}=64 \\
\text { intervention group }\end{array}$ & $\begin{array}{l}\text { The intervention } \\
\text { is the } \\
\text { implementation } \\
\text { of quiet-time } \\
\text { protocols. } \\
\text { The control } \\
\text { group had no } \\
\text { quiet-time } \\
\text { protocols } \\
\text { The tool used } \\
\text { was a survey of } \\
\text { patient's } \\
\text { perception of } \\
\text { rest during their } \\
\text { post-partum } \\
\text { hospital stay. }\end{array}$ & $\begin{array}{l}\text { Florence } \\
\text { Nightingale's } \\
\text { statement on } \\
\text { the } \\
\text { detrimental } \\
\text { effects of } \\
\text { noise for } \\
\text { patients. }\end{array}$ & $\begin{array}{l}\text { To determine if } \\
\text { quiet-times } \\
\text { promote baby- } \\
\text { mother } \\
\text { bonding and } \\
\text { improve post- } \\
\text { partum rest. }\end{array}$ & $\begin{array}{l}\text { This study found } \\
\text { no change } \\
\text { between the } \\
\text { intervention and } \\
\text { control groups. }\end{array}$ \\
\hline Younis et al., (2020). & $\mathrm{I}-\mathrm{B}$ & $\begin{array}{l}\text { A convenience sample of } \\
\text { patients admitted to the ICU. } \\
n=103\end{array}$ & $\begin{array}{l}\text { Test if there is a } \\
\text { correlation } \\
\text { between ICU }\end{array}$ & $\begin{array}{l}\text { No } \\
\text { theoretical }\end{array}$ & $\begin{array}{l}\text { Test if there is } \\
\text { a correlation } \\
\text { between ICU }\end{array}$ & $\begin{array}{l}\text { Noise was noted } \\
\text { as an } \\
\text { environmental }\end{array}$ \\
\hline
\end{tabular}




\begin{tabular}{|c|c|c|c|c|c|c|}
\hline & & & $\begin{array}{l}\text { environment and } \\
\text { patients sleep } \\
\text { quality. } \\
\text { Tools used were } \\
\text { the Freedman } \\
\text { Quality of Sleep } \\
\text { Scale, and the } \\
\text { Richards- } \\
\text { Campbell Sleep } \\
\text { Scale }\end{array}$ & $\begin{array}{l}\text { foundation } \\
\text { was stated }\end{array}$ & $\begin{array}{l}\text { environment } \\
\text { and patients } \\
\text { sleep quality. }\end{array}$ & $\begin{array}{l}\text { factor for sleep } \\
\text { disturbances. } \\
\text { Recommendation } \\
\text { s were made with } \\
\text { no real evidence } \\
\text { to support them. }\end{array}$ \\
\hline Zamani et al., (2018). & II-A & $\begin{array}{c}\text { No test subjects were used. } \\
\text { Sound levels were monitored } \\
\text { prior to and after training on } \\
\text { noise pollution. }\end{array}$ & $\begin{array}{l}\text { The intervention } \\
\text { was } \\
\text { implementation } \\
\text { of staff training } \\
\text { on sound } \\
\text { pollution. } \\
\text { Sound } \\
\text { monitoring } \\
\text { equipment was } \\
\text { used to } \\
\text { determine before } \\
\text { and after sound } \\
\text { levels }\end{array}$ & $\begin{array}{l}\text { No } \\
\text { theoretical } \\
\text { foundation } \\
\text { was stated }\end{array}$ & $\begin{array}{l}\text { Outcome is to } \\
\text { decrease noise } \\
\text { levels after the } \\
\text { implementatio } \\
\text { n of staff } \\
\text { training on } \\
\text { sound } \\
\text { pollution. }\end{array}$ & $\begin{array}{l}\text { Noise levels } \\
\text { decreased } \\
\text { significantly after } \\
\text { staff training }\end{array}$ \\
\hline
\end{tabular}




\section{Appendix C}

\section{SWOT Analysis}

\begin{tabular}{|l|l|}
\hline \multicolumn{1}{|c|}{ INTERNALFACTORS } \\
\hline \multicolumn{1}{|c|}{ SIRENG THS(+) } & \multicolumn{1}{c|}{ WEAKNESSES (-) } \\
\hline $\begin{array}{l}\text { Senior leadership embraces change } \\
\text { forimprovement }\end{array}$ & - Organization currently und ergoing \\
- Organization is forward thinking & $\begin{array}{l}\text { organizational restruc turing } \\
\text { Space in the facility is limited }\end{array}$ \\
\hline
\end{tabular}

\begin{tabular}{|c|c|}
\hline \multicolumn{2}{|c|}{ EXTERNALFACTORS } \\
\hline OPPORIUNITIES (+) & THREATS (-) \\
\hline $\begin{array}{l}\text { - Improving patient satisfaction with } \\
\text { noise. } \\
\text { - Expansion of the fa cility }\end{array}$ & $\begin{array}{l}\text { - Large competing hosp ital in the a rea } \\
\text { Other facilities outside of the } \\
\text { immediate a rea that provide similar } \\
\text { services }\end{array}$ \\
\hline
\end{tabular}




\section{Appendix D}

\section{PowerPoint for Staff Training}

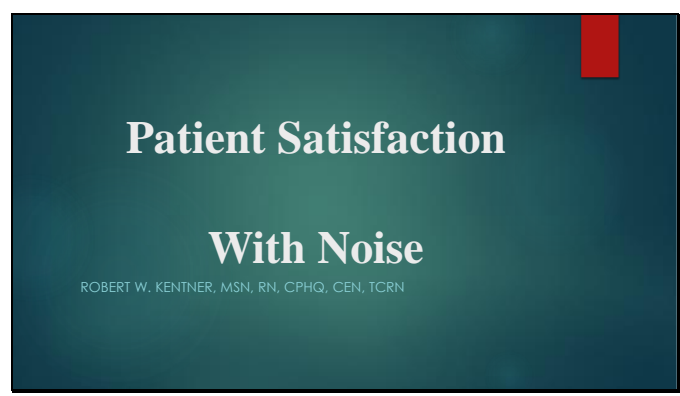

Effects of Noise on Patients

$\checkmark$ Poor Rest

- Delayed Healing

$\checkmark$ Hypertension

$>$ Stress

Hyperglycemia

$>$ Low Satisfaction

(Duss et all, 2017; stewart \& Arora, 2018; Zhang et al, 2020)

Noise Mitigation

- Reduce Volume on Monitor Alarms

$\checkmark$ Reduce Volume on IV Pump Alarms

$\checkmark$ Limit Staff Conversations

$\checkmark$ Close Doors

$\checkmark$ Designated Quiet-Time

$\checkmark$ Sleep Time Menu

(Applebaum et al., 2016; Clark \& Mills, 2017; Delanev et all, 2018; Kaur et all, 2016; Stickland
et al, 2016)

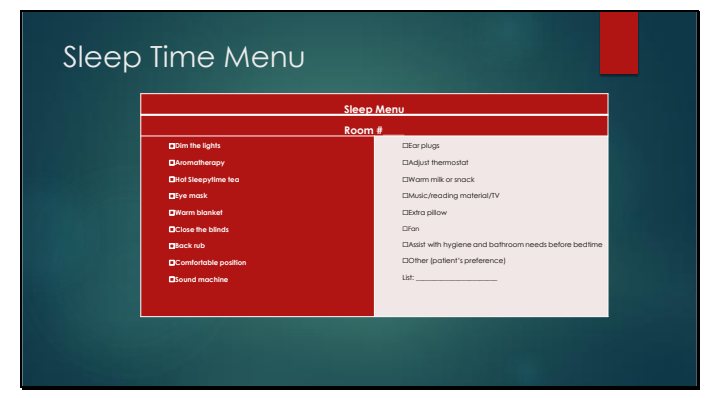

\section{Background}

- Florence Nightingale

$\checkmark$ HCAHPS Scores

- Normal Conversation $60 \mathrm{~dB}$

- World Health Organization

$\triangleright<30 \mathrm{~dB}$ at night

$\diamond<35 \mathrm{~dB}$ during the day

$\gg 45$ dB Sleep Disturbance

(Berglund et all, 1999; Center for Disease Control and Prevention, 2019; Centers for
Medicare and Medicid Senvices nd. Nightingale 1860)

\section{Sources of Noise}

\section{$\checkmark$ Monitor Alarms}

- IV Pump Alarms

$\checkmark$ Staff Conversations

$\checkmark$ Family Conversations

$\checkmark$ Other Patients

$\checkmark$ Ventilation

> Carts in hallways

(Applebaum et al, 2016; Christofel et all, 2016; Delaney et all, 2017; Ryan et all, 2016
Stremler et al . 2015)

\section{Quiet-Time}

$\checkmark 1$ P.M. to 3 P.M. Daily

$\checkmark$ Dim Lights

$>$ Close Doors

- Minimize Patient Interactions

- Schedule Medications for Other Times

- Schedule Procedures for Other Times

> Physicians Round Outside of Quiet-Time

(Kaur et al., 2016; Rice, 2010; Steaphen et al., 2017)
Monitoring Tools

Patient Survey

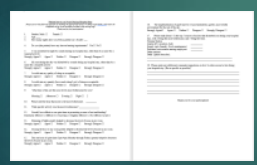

(Applebaum et al, 2016; REED Instruments, n.. I)
Sound Level Meter

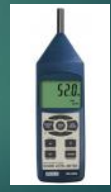



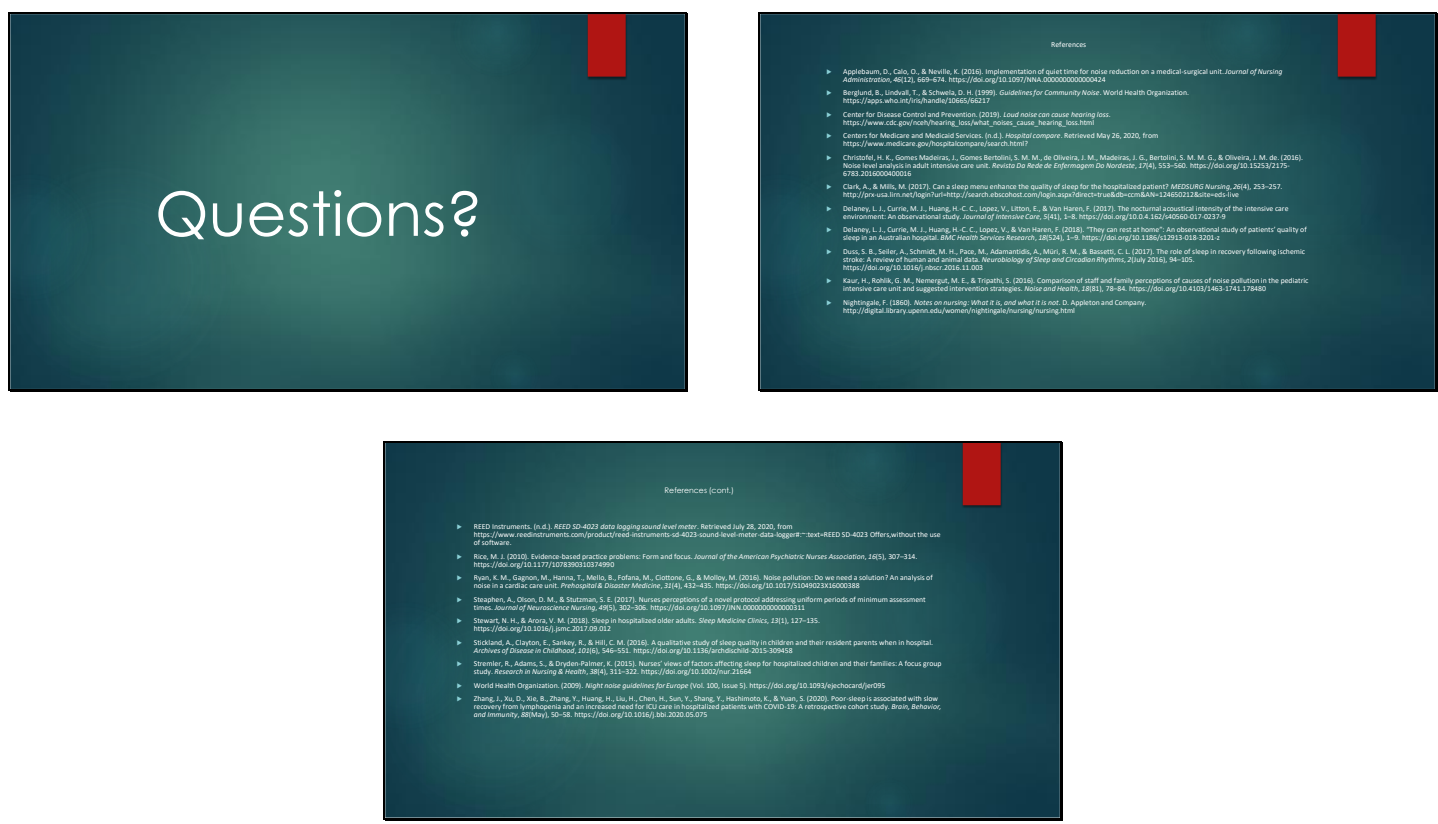


\section{Appendix E}

\section{Patient Survey on Noise During Hospital Stay}

Please answer the following questions by marking the appropriate box(es) or filling in the blanks, and return the completed survey in the envelope provided to the nursing staff.

Thank you for your participation!

1. Gender: Male $\square \quad$ Female

2. Age

3. How many nights have you been a patient on Medical-Surgical Unit?

4. Do you (the patient) have any known hearing impairments? Yes $\square$ No $\square$

5. I was awakened at night by sounds during my hospital stay, other than by a nurse for a required activity

Strongly Agree $\square \quad$ Agree $\square \quad$ Neither $\square \quad$ Disagree $\square \quad$ Strongly Disagree $\square$

6. My rest during the day was disturbed by sounds during my hospital stay, other than by a nurse for a required activity

Strongly Agree $\square \quad$ Agree $\square \quad$ Neither $\square \quad$ Disagree $\square \quad$ Strongly Disagree

7. I would rate my quality of sleep as acceptable.

Strongly Agree $\square \quad$ Agree $\square \quad$ Neither $\square \quad$ Disagree $\square \quad$ Strongly Disagree

8. I would rate my quantity (how much sleep I got) of sleep as acceptable.

Strongly Agree $\square \quad$ Agree $\square \quad$ Neither $\square \quad$ Disagree $\square \quad$ Strongly Disagree $\square$

9. What time of day are the noise levels most bothersome for you?

Morning $\square \quad$ Afternoon $\square \quad$ Evening $\square \quad$ Night $\square$

10. Please state the hour that noise is the most bothersome.

11. What specific activity was the most troublesome?

12. Overall, how effective was quiet time in promoting a sense of rest and healing? Extremely effective $\square$ Effective $\square$ Uncertain $\square$ Slightly effective $\square$ Not effective at all $\square$

13. Dimming of lights greatly helped to decrease the level of noise in my room.

Strongly Agree $\square \quad$ Agree $\square \quad$ Neither $\square \quad$ Disagree $\square \quad$ Strongly Disagree $\square$

14. Closing the door to my room greatly helped to decrease the level of noise in my room.

Strongly Agree $\square \quad$ Agree $\square \quad$ Neither $\square \quad$ Disagree $\square \quad$ Strongly Disagree $\square$ 
15. The two hour of quiet time (1 p.m. -3 p.m.) greatly helped to decrease the level of noise in my room.

Strongly Agree $\square \quad$ Agree $\square \quad$ Neither $\square \quad$ Disagree $\square \quad$ Strongly Disagree $\square$

16. The implementation of quiet time for 2 hour facilitated a quieter, more restful environment for the rest of the day.

Strongly Agree $\square \quad$ Agree $\square \quad$ Neither $\square \quad$ Disagree $\square \quad$ Strongly Disagree $\square$

17. Please rank (from 1-5) the top 5 sources of noises that disturbed you during your hospital stay, with 1 being the most bothersome, and 5 being the least.

Nursing Station

Alarms (IV, monitors, bed)

Supply carts (laundry, food, maintenance)

Personnel conversation among employees

Other patients

Other (please describe):

18. Please make any additional comments/suggestions on how to reduce noise levels during your hospital stay. (Be as specific as possible).

Thank you for your participation! 


\section{Appendix F}

\section{Permission to Use the Patient Survey on Noise During Hospital Stay}

\section{Re: DNP Student Project}

2 messages

Diane Applebaum <d_applebaum@hotmail.com>

To: Robert W Kentner <R.Kentner@usa.edu>

Wed, Jul 1, 2020 at 11:57 AM

Hello Bob,

Attached is a copy of the Patient Survey on Noise During Hospital Stay for your use. We actually developed this tool for our project since we were not able to find one to meet our needs. You have my permission to use this tool.

Best of luck with your research!

Diane

From: Robert W Kentner <R.Kentner@usa.edu>

Sent: Saturday, June 27, 2020 11:46 PM

To: d_applebaum@hotmail.com<d_applebaum@hotmail.com>

Subject: DNP Student Project

My name is Bob Kentner, and I am a Doctor of Nursing Practices student. I am currently working on my practicum and change project. My change project is focused on patient satisfaction with noise. You published a study in the Journal of Nursing Administration titled "Implementation of Quiet Time for Noise Reduction on a Medical-Surgical Unit" In this study, you used a tool title Patient Survey on Noise During Hospital Stay. I am hoping to obtain a copy of this survey and permission to possibly use it in my project.

Any assistance you can provide would be greatly appreciated. Please feel free to contact me with any questions.

Bob Kentner, MSN, RN, CPHQ, CEN, TCRN

MSN - Entry Student

Doctor of Nursing Practice Program

School of Nursing

Post-Professional Programs

University of Saint Augustine for Health Sciences

Personal Cell: (402) 404-1325 (MT)

W] Appendix F Noise Survey Tool Final.docx

$15 \mathrm{~K}$

Bob Kentner <bob@kentner.org>

Wed, Jul 1, 2020 at 12:29 PM

To: Diane Applebaum <d_applebaum@hotmail.com>

Thank you very much. 


\section{Appendix G}

\section{Project Schedule}

\begin{tabular}{|c|c|c|c|c|c|c|c|c|c|c|c|c|c|c|c|c|c|c|c|c|c|c|c|c|}
\hline \multirow[b]{2}{*}{ Activity } & \multicolumn{8}{|c|}{ NUR7801 } & \multicolumn{8}{|c|}{ NUR7802 } & \multicolumn{8}{|c|}{ NUR7803 } \\
\hline & $\begin{array}{l}\mathrm{w} \\
\mathrm{e} \\
\mathrm{e} \\
\mathrm{k} \\
1\end{array}$ & $\begin{array}{l}\text { W } \\
\mathrm{e} \\
\mathrm{e} \\
\mathrm{k} \\
3\end{array}$ & $\begin{array}{l}\text { W } \\
\text { e } \\
\text { e } \\
\text { k } \\
5\end{array}$ & $\begin{array}{l}\text { W } \\
\mathrm{e} \\
\mathrm{e} \\
\mathrm{k} \\
7\end{array}$ & $\begin{array}{l}\mathrm{W} \\
\mathrm{e} \\
\mathrm{e} \\
\mathrm{k} \\
9\end{array}$ & $\begin{array}{l}\mathrm{W} \\
\mathrm{e} \\
\mathrm{e} \\
\mathrm{k} \\
1 \\
1\end{array}$ & $\begin{array}{l}\text { W } \\
\text { e } \\
\text { e } \\
k \\
1 \\
3\end{array}$ & $\begin{array}{l}\text { W } \\
\mathrm{e} \\
\mathrm{e} \\
\mathrm{k} \\
1 \\
5\end{array}$ & $\begin{array}{l}\mathrm{W} \\
\mathrm{e} \\
\mathrm{e} \\
\mathrm{k} \\
1\end{array}$ & $\begin{array}{l}\mathrm{W} \\
\mathrm{e} \\
\mathrm{e} \\
\mathrm{k} \\
3\end{array}$ & $\begin{array}{l}\mathrm{W} \\
\mathrm{e} \\
\mathrm{e} \\
\mathrm{k} \\
5\end{array}$ & $\begin{array}{l}\text { W } \\
\mathrm{e} \\
\mathrm{e} \\
\mathrm{k} \\
7\end{array}$ & $\begin{array}{l}\mathrm{W} \\
\mathrm{e} \\
\mathrm{e} \\
\mathrm{k} \\
9\end{array}$ & $\begin{array}{l}\mathrm{W} \\
\mathrm{e} \\
\mathrm{e} \\
\mathrm{k} \\
1 \\
1\end{array}$ & $\begin{array}{l}\mathrm{W} \\
\mathrm{e} \\
\mathrm{e} \\
\mathrm{k} \\
1 \\
3\end{array}$ & $\begin{array}{l}\mathrm{W} \\
\mathrm{e} \\
\mathrm{e} \\
\mathrm{k} \\
1 \\
5\end{array}$ & $\begin{array}{l}\text { W } \\
\mathrm{e} \\
\mathrm{e} \\
\mathrm{k} \\
1\end{array}$ & $\begin{array}{l}\mathrm{W} \\
\mathrm{e} \\
\mathrm{e} \\
\mathrm{k} \\
3\end{array}$ & $\begin{array}{l}\mathrm{W} \\
\mathrm{e} \\
\mathrm{e} \\
\mathrm{k} \\
5\end{array}$ & $\begin{array}{l}\text { W } \\
\mathrm{e} \\
\mathrm{e} \\
\mathrm{k} \\
7\end{array}$ & $\begin{array}{l}\mathrm{W} \\
\mathrm{e} \\
\mathrm{e} \\
\mathrm{k} \\
9\end{array}$ & $\begin{array}{l}\text { W } \\
\mathrm{e} \\
\mathrm{e} \\
\mathrm{k} \\
1 \\
1\end{array}$ & $\begin{array}{l}\mathrm{W} \\
\mathrm{e} \\
\mathrm{e} \\
\mathrm{k} \\
1 \\
3\end{array}$ & $\begin{array}{l}\text { W } \\
\mathrm{e} \\
\mathrm{e} \\
\mathrm{k} \\
1 \\
5\end{array}$ \\
\hline $\begin{array}{l}\text { Prepare project } \\
\text { proposal }\end{array}$ & & & & & & & & & & & & & & & & & & & & & & & & \\
\hline $\begin{array}{l}\text { Gain Hospital } \\
\text { Approval for Project }\end{array}$ & & & & & & & & & & & & & & & & & & & & & & & & \\
\hline $\begin{array}{l}\text { Develop Public } \\
\text { Education Campaign }\end{array}$ & & & & & & & & & & & & & & & & & & & & & & & & \\
\hline Train Supervisors & & & & & & & & & & & & & & & & & & & & & & & & \\
\hline Train Staff & & & & & & & & & & & & & & & & & & & & & & & & \\
\hline $\begin{array}{l}\text { Install Sound } \\
\text { Monitoring Equipme }\end{array}$ & & & & & & & & & & & & & & & & & & & & & & & & \\
\hline $\begin{array}{l}\text { Install Quiet Time } \\
\text { Signs }\end{array}$ & & & & & & & & & & & & & & & & & & & & & & & & \\
\hline $\begin{array}{l}\text { Look for and Identify } \\
\text { Possible sources of } \\
\text { Noise }\end{array}$ & & & & & & & & & & & & & & & & & & & & & & & & \\
\hline $\begin{array}{l}\text { Collect Pre- } \\
\text { implementation Noi } \\
\text { and Survey Data }\end{array}$ & & & & & & & & & & & & & & & & & & & & & & & & \\
\hline $\begin{array}{l}\text { Implement Public } \\
\text { Education Campaign }\end{array}$ & & & & & & & & & & & & & & & & & & & & & & & & \\
\hline $\begin{array}{l}\text { Implement Hospital } \\
\text { Noise Program }\end{array}$ & & & & & & & & & & & & & & & & & & & & & & & & \\
\hline Collect Final Data & & & & & & & & & & & & & & & & & & & & & & & & \\
\hline Write Project Report & & & & & & & & & & & & & & & & & & & & & & & & \\
\hline $\begin{array}{l}\text { Present Findings to } \\
\text { Senior Leadership }\end{array}$ & & & & & & & & & & & & & & & & & & & & & & & & \\
\hline $\begin{array}{l}\text { Implement } \\
\text { Sustainability Plan }\end{array}$ & & & & & & & & & & & & & & & & & & & & & & & & \\
\hline
\end{tabular}




\section{Appendix $\mathbf{H}$}

\section{Budget}

\begin{tabular}{|l|l|}
\hline EXPENSES & \\
\hline Paper & $\$ 20.00$ \\
\hline REED Instruments R8070SD Sound Level Meter, & $\$ 500.00$ \\
\hline TestHelper SW-525A Sound Level Meter Tester & $\$ 60.00$ \\
\hline 30-130db Large Screen LCD Display & \\
\hline One hour labor for facilities to install sound meter & $\$ 50.00$ \\
\hline Total & $\$ 630.00$ \\
\hline & \\
\hline & \\
\hline & \\
\hline & \\
\hline & \\
\hline & \\
\hline
\end{tabular}




\section{Appendix I}

\section{Sleep Menu}

\begin{tabular}{|l|c|}
\hline \multicolumn{2}{|c|}{ Sleep Menu } \\
\hline & Room \# \\
\hline$\square$ Dim the lights & $\square$ Ear plugs \\
$\square$ Aromatherapy & $\square$ Adjust thermostat \\
$\square$ Hot Sleepytime tea & $\square$ Warm milk or snack \\
$\square$ Eye mask & $\square$ Music/reading material/TV \\
$\square$ Warm blanket & $\square$ Extra pillow \\
$\square$ Close the blinds & $\square$ Assist with hygiene and \\
$\square$ Back rub & bathroom needs before bedtime \\
$\square$ Comfortable position & $\square$ Other (patient's preference) \\
$\square$ Sound machine & List: \\
$\square$ Fan & \\
& \\
\end{tabular}

